\title{
An examination of species limits in the Aulacorhynchus "prasinus" toucanet complex (Aves: Ramphastidae)
}

\author{
Kevin Winker ${ }^{\text {Corresp. } 1}$ \\ 1 University of Alaska Museum, University of Alaska Fairbanks \\ Corresponding Author: Kevin Winker \\ Email address: kevin.winker@alaska.edu
}

The number of species recognized in Aulacorhynchus toucanets has varied tremendously over the past century. Revisors seem to disagree on whether head and bill coloration are useful indicators of species limits, especially in the A. "prasinus" complex. Using morphometrics, I tested the hypothesis that the major color-based subspecific groups of $A$. "prasinus" sensu lato are simply "cookie-cutter" (i.e., morphologically nearly identical) toucanets with different head and bill colorations. Univariate and multivariate analyses show that they are not simply morphological replicates of different colors: a complex array of morphometric similarities and dissimilarities occur between the major subspecific groups, and these variations differ between the sexes. Latitude and longitude had a small but significant association with female (but not male) PC1 and PC2. Hybridization and intergradation were also considered using plumage and bill characters as a surrogate to infer gene flow. Hybridization as indicated by phenotype appears to be substantial between $A$. "p." cyanolaemus and $A$. " $p$." atrogularis and nonexistent between other major groups, although from genetic evidence it is likely rare between $A$. " $p$." albivitta and $A$. "p." cyanolaemus. The congruence and complexities of the morphological and color changes occurring among these groups suggest that ecological adaptation (through natural selection) and social selection have co-occurred among these groups and that species limits are involved. Further, hybridization is not evident at key places, despite in many cases (hypothetical) opportunity for gene flow. Consequently, I recommend that this complex be recognized as comprising five biological species: A. wagleri, prasinus, caeruleogularis, albivitta, and atrogularis. Four of these also have valid subspecies within them, and additional work may eventually support elevation of some of these subspecies to full species. Species limits in South America especially need more study. 


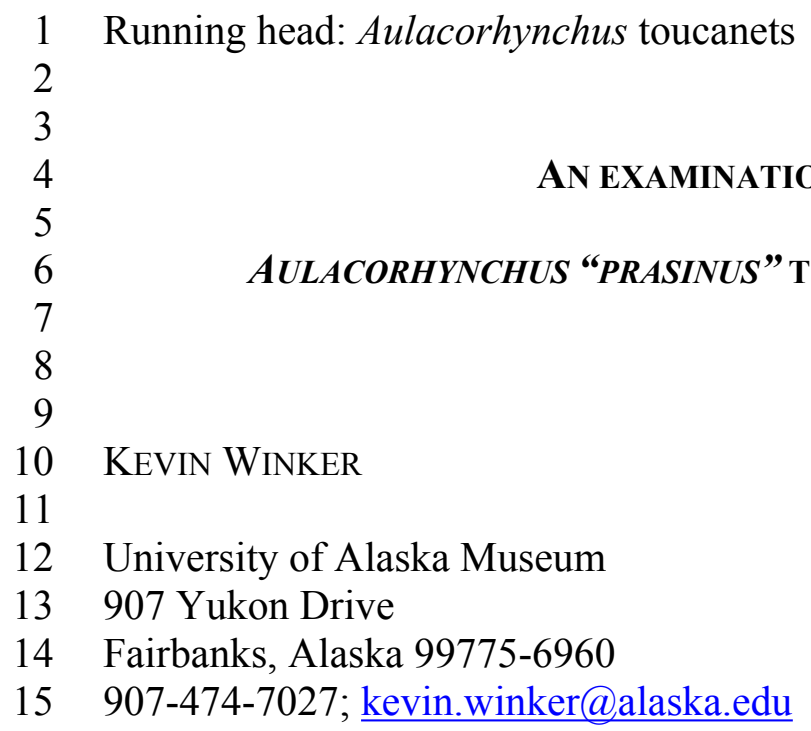

University of Alaska Museum 907 Yukon Drive

14 Fairbanks, Alaska 99775-6960

15 907-474-7027; kevin.winker@alaska.edu

10 KEVIN WINKER

11

16

17

18

19

20

21

22

23

24

25

26

27

28 
29 Abstract.-The number of species recognized in Aulacorhynchus toucanets has varied

30 tremendously over the past century. Revisors seem to disagree on whether head and bill

31 coloration are useful indicators of species limits, especially in the $A$. "prasinus" complex. Using

32 morphometrics, I tested the hypothesis that the major color-based subspecific groups of $A$.

33 "prasinus" sensu lato are simply "cookie-cutter" (i.e., morphologically nearly identical)

34 toucanets with different head and bill colorations. Univariate and multivariate analyses show that

35 they are not simply morphological replicates of different colors: a complex array of

36 morphometric similarities and dissimilarities occur between the major subspecific groups, and

37 these variations differ between the sexes. Latitude and longitude had a small but significant association with female (but not male) PC1 and PC2. Hybridization and intergradation were also considered using plumage and bill characters as a surrogate to infer gene flow. Hybridization as indicated by phenotype appears to be substantial between $A$. "p." cyanolaemus and $A$. "p." atrogularis and nonexistent between other major groups, although from genetic evidence it is likely rare between $A$. " $p$." albivitta and A. "p." cyanolaemus. The congruence and complexities of the morphological and color changes occurring among these groups suggest that ecological adaptation (through natural selection) and social selection have co-occurred among these groups and that species limits are involved. Further, hybridization is not evident at key places, despite in many cases (hypothetical) opportunity for gene flow. Consequently, I recommend that this complex be recognized as comprising five biological species: $A$. wagleri, prasinus, caeruleogularis, albivitta, and atrogularis. Four of these also have valid subspecies within them, and additional work may eventually support elevation of some of these subspecies to full species. Species limits in South America especially need more study. 
In spite of ongoing advances in the description and recognition of biodiversity, few

55

\section{Taxonomic History}

In the second edition of his monograph on the Ramphastidae, Gould (1854) recognized remained undescribed at that time. Between them, Salvin \& Godman (1896) and Brabourne \& Chubb (1912) recognized 15 species in the genus. Ridgway (1914) followed this treatment. Cory (1919) considered one of these species (A. erythrognathus) to be only a subspecies, and he treated the genus as having 14 species. Although a new species was described in $1933(A$. huallagae, Carriker, 1933), Peters (1948) reduced many of the formerly recognized species to subspecific status and presented the species-level diversity of the genus as just seven taxa. Haffer (1974) followed Peters (1948), except that he reduced one species (A. calorhynchus) to subspecies status (after Schwartz, 1972), leaving just six. Sibley \& Monroe (1990) followed this treatment, but they presented a further reduction of the apparent diversity by mentioning only two subspecific groups below the species level. Although more comprehensive subspecific inclusion and discussion were given by Short \& Horne (2001, 2002), six full species were retained. The treatment of this genus since 1891 is summarized in Table 1. The massive lumping of Peters (1948) proceeded with neither the presentation of data nor 
76 with discussion. Careful study of one taxon, A. calorhynchus, by Schwartz (1972) supported the

77 single species-level change that was made between Peters (1948) and Haffer (1974), and

78 Haffer's (1974) important work has been cited to support maintaining a broad A. prasinus (sensu

79 lato; AOU, 1998). Haffer (1974) and Short \& Horne $(2001,2002)$ used evidence of hybridization

80 and intergradation to support their conclusions that the whole $A$. "prasinus" complex

81 represented one biological species with many subspecies (14 and 13 subspecies, respectively); at

82 the species level across the genus Short \& Horne's $(2001,2002)$ treatment reflected that of

83 Dickinson \& Remsen (2013) in Table 1 except that they considered $A$. whitelianus a subspecies

84 of A. derbianus, as Peters (1948) did. Presumably similar reasoning was behind Peters (1948).

85 But subspecies, even those distinctive enough to have been considered full species for a century,

86 can get lost in the shuffle. For example, oversimplification of subspecific variation led Sibley \&

87 Monroe (1990) and the American Ornithologists' Union (AOU, 1983, 1998) to completely omit

88 mention of the very distinct form A. "prasinus" wagleri from southwestern Mexico. The AOU

89 (1983, 1998) considered Middle American diversity in the genus as being just two subspecific

90 groups of a single species, A. prasinus.

91 Renewed interest in this complex (Navarro et al., 2001; Puebla-Olivares et al., 2008;

92 Bonaccorso et al., 2011; del Hoyo \& Collar, 2014) is beginning to rectify the absence of data, but

93 the ensuing taxonomic changes recommended have either been based on a different species

94 concept (Bonaccorso et al., 2011) or have inadequately considered the hybridization and

95 intergradation (e.g., Navarro et al., 2001; Puebla-Olivares et al., 2008; del Hoyo \& Collar, 2014)

96 that have been integral to supporting the "post-Peters" taxonomy. These latter works have

97 recommended elevation of numerous $A$. "prasinus" taxa to species status (Table 1), but they did

98 not address the reasons for lumping in the first place: evidence of hybridization. There has also 
99 been heavy reliance on a single molecular marker (mtDNA) for species delimitation in $A$.

100 "prasinus" (Puebla-Olivares et al., 2008; Bonaccorso et al., 2011). This is problematic because

101 mtDNA can be misleading about species limits and relationships between populations due to

102 gene-tree/species-tree mismatches and because genetic distance is not a reliable indicator of

103 species limits (Avise \& Wollenberg, 1997; Irwin, 2002; Funk \& Omland, 2003; Degnan \&

104 Rosenberg, 2006; Cheviron \& Brumfield, 2009; Galtier et al., 2009; Ribeiro et al., 2011; Toews

105 \& Brelsford, 2012; Pavlova et al., 2013; Peters et al., 2014; Dolman \& Joseph, 2015; Morales et

106 al., 2015). Thus, species limits in the group remain uncertain (Table 1). Most disagreement has

107 been in the $A$. "prasinus" complex, and it is on this group that I focus.

The A. "prasinus" complex.—As currently treated (e.g., Table 1, Dickinson \& Remsen,

109 2013; del Hoyo \& Collar, 2014), A. "prasinus" either is a widely distributed and highly variable

110 biological species or it comprises multiple species (Fig. 1). So far as is known, Aulacorhynchus

111 toucanets are nonmigratory (AOU, 1998), but as O'Neill \& Gardner (1974) and Navarro et al.

112 (2001) noted, members of the genus can wander widely during the nonbreeding season. Short \&

113 Horne (2001) considered Central American forms from Mexico to Panama to be partially

114 migratory, with downslope movements to lowlands also occurring during the nonbreeding season

115 (but less commonly) throughout the $A$. "prasinus" range. The sexes are alike by plumage

116 (sexually monochromatic), but sexual size dimorphism is apparent in all taxa examined.

117 In past work there has been too little discussion of the fact that different levels of

118 differentiation occur among the subspecies of $A$. prasinus, sensu lato. All of the named forms do

119 not represent equally differentiated populations; there are major subspecific groups of one or

120 more described subspecies. Objectively determining what these groups are can be done by

121 following taxonomic history, coupled as it is with a color-based clustering. Cory (1919) 
122 recognized eight species that were later lumped by Peters (1948) into A. prasinus (Table 1). It

123 seems that four of these (A. wagleri, lautus, cyanolaemus, and dimidiatus) were not available for

124 Cory (1919) to examine, however (he noted which taxa were in the Field Museum of Natural

125 History at that time). Two of these taxa, A. lautus and A. dimidiatus, may have been included as

126 full species through intertia. This was not uncommon: Ridgway (1914) considered that the genus

127 had 15 species, but he was uncertain because he had only been able to examine seven of them.

128 The subsequent rediscovery and examination of $A$. dimidiatus (O'Neill \& Gardner, 1974) showed

129 intergradation with $A$. "prasinus" atrogularis, and the Santa Marta isolate A. "prasinus" lautus

130 is, by plumage, clearly a relatively minor derivative of the $A$. " $p$." albivitta group. These

131 considerations reduce the number of major, color-based subspecific groups in the $A$. "prasinus"

132 complex to six (A. “p." wagleri, prasinus, caeruleogularis, albivitta, cyanolaemus, and

133 atrogularis).

134 The rather pronounced differences among these major groups are illustrated in Fig. 1,

135 together with examples of some of the less-pronounced variation (though still between named

136 subspecies) occurring within two of these groups. Del Hoyo \& Collar (2014) presented an

137 analysis of colors that reaffirms this approach, coming back to the same six color-based

138 subspecific groups and treating them as full biological species. Diagnostic characters of these six

139 groups are given in Table 2. It is these six groups that form the basis for my comparisons. They

140 are the color-based groupings that have been recognized by students of the birds themselves.

141 The troubled taxonomic history of Aulacorhynchus (especially A. prasinus, sensu lato)

142 reflects disagreement among revisors over the ability of plumage and bill colors and patterns to

143 represent species limits. Members of the $A$. "prasinus" group in particular are effectively

144 ecologically similar geographic replacements (Mallet, 2007), and where named taxa have been 
145 found to come together hybridization has been described (e.g., Haffer, 1974; Short \& Horne,

146 2001). Given evidence of hybridization, it is unclear how the birds themselves perceive these

147 differences. Is this group (A. "prasinus"sensu lato) really one in which head and bill colors and

148 patterns are very plastic, resulting in species that include a high degree of color variation? Or are

149 full species being overlooked? If bill and head color characteristics are plastic and not indicative

150 of species limits, as many treatments since 1948 suggest, then strikingly color-based taxa, most

151 of Cory's (1919) species and the six of del Hoyo \& Collar (2014), would not likely show a great

152 deal of morphometric distinctiveness. If, on the other hand, substantial, concordant

153 morphological changes are also occurring, then perhaps the concept of ecologically similar

154 geographic replacements, which seems broadly applicable to $A$. prasinus, sensu lato, is masking

155 important group-specific evolutionary adaptations that go beyond the existing color changes, the

156 latter of which likely reflect social selection. Such morphological differences might suggest

157 adaptive changes among groups that would make immigrants and hybrids less fit (Price, 2008).

158 My question then is simple: Are these color-based subspecific groups just "cookie-cutter" (i.e.,

159 morphologically nearly identical) toucanets bearing different throat and bill colorations, or are

160 there also significant morphological changes occurring among them? If substantial morphometric

161 changes occur concurrently with dramatic color changes, then species limits should probably be

162 reconsidered, as several have suggested (Navarro et al., 2001; Puebla-Olivares et al., 2008;

163 Bonaccorso et al., 2011; del Hoyo and Collar, 2014).

164 Morphometrics alone are unlikely to be important components of species limits in forms

165 like these where colors are obviously important, and this is not meant as a study of how

166 morphology varies within the group independently of color-based clustering. Navarro et al.

167 (2001) did a morphological analysis based on 17 allopatric groupings, and this is not meant to 
168 repeat those analyses. Geography alone can affect morphology (e.g., Bergmann's rule; Mayr,

169 1963), and my analyses account for this. In this study I will 1) test for univariate differences

170 between pairwise groups that are geographically closest to each other; 2) compare these groups

171 in multivariate, principal component space (because univariate measures can be correlated with

172 each other); and 3) visually examine specimens for evidence of hybridization because such

173 evidence has been historically important in the taxonomy of the group.

\section{METHODS AND RESULTS}

I used morphometrics to examine how body characteristics vary among the major, colorbased subspecific groups in the Aulacorhynchus "prasinus" complex (Fig. 1, Table 2). Museum specimens (institutions listed in Acknowledgments) were visually examined and measurements of wing chord, tail, tarsometatarsus, bill, bill height, and bill width (all three bill measures from anterior edge of nares) were made to the nearest $0.1 \mathrm{~mm}$ using vernier calipers following Baldwin, Oberholser \& Worley (1931). Wing tip (length of longest primary to first secondary) was also measured to the nearest $0.1 \mathrm{~mm}$ using vernier calipers. Although Navarro et al. (2001) raised the possibility that bill growth in this group might be indeterminate, with my larger sample size of 98 male $A$. prasinus sensu stricto (see Appendix) I found that bill length had a normal distribution, so it is retained in my analyses. Morphometric geographic variation within these six major subspecific groups was not examined, because that is not related to the hypothesis being tested, i.e., are morphological changes occurring concurrently with color-based changes (see also

187 Navarro, 2001). However, the effects of geography upon the data are examined after the main questions posed are addressed. Some of these major subspecific "groups" have named subspecies within them. Aulacorhynchus prasinus has four (prasinus, warneri, virescens, volcanius), A.

190 “p.” caeruleogularis two (caeruleogularis, cognatus), A. “p.” albivitta four (lautus, 
191 griseigularis, phaeolaemus, albivitta), and A. “p." atrogularis two (atrogularis, dimidiatus); the

192 other two major subspecific groups (wagleri, and cyanolaemus) have no named subspecies

193 within them (Appendix). Color differences formed the basis for the majority of characters used

194 to describe all of these named subspecies, with size being mentioned (in addition to color) in just

195 three of 14 cases. Within-group variation is accounted for in the standard statistical manner (e.g.,

196 Table 3). Immature individuals were not measured.

197 I examined and measured 578 specimens of the six major subspecific groups of $A$.

198 "prasinus." The distributions of these groups (Fig. 2) were found to be allopatric or parapatric, as

199 others have depicted (e.g., Haffer, 1974; Short \& Horne, 2001; Ridgely \& Greenfield, 2001;

200 Restall, Rodner \& Lentino, 2006). Morphometric data exhibited male-biased sexual size

201 dimorphism (Table 3), so all analyses were performed separately for each sex.

202 Univariate mensural characteristics (Table 3) were visually examined to determine

203 whether it was warranted to apply statistical testing for differences. This was done to reduce the

204 overall number of tests made, which enhances the power of individual tests when applying

205 multiple-test corrections. No statistical tests were done on mass (due to small sample sizes), and

206 tests were applied in a pairwise manner between groups most proximate to each other (except for

207 A. "prasinus" albivitta-atrogularis). The Bonferroni-style of multiple-test correction is highly

208 conservative, so I did not use it; in controlling for table-wide Type I error (rejecting the null

209 hypothesis when it is true), it raises the likelihood of Type II error (incorrectly accepting the null

210 hypothesis) at the level of the single test (Sokal \& Rohlf, 1995; Whitlock \& Schluter, 2009).

211 While false discoveries will accrue with multiple testing, determining whether there are

212 differences at the individual test level is very important for a study of this type. I used an

213 approach more commensurate with this need, one that controls for the expected proportion of 
214 falsely rejected null hypotheses, the "false discovery rate" (Benjamini \& Hochberg, 1995). I

215 report both aspects (uncorrected and corrected), because future investigators of subsets of these

216 taxa should focus on characteristics that differ between them and not be distracted by the

217 additional statistical gyrations that I needed to perform to reduce table-wide error when making

218 so many tests (60 tests for Table 4 and 24 for Table 5).

219 Significant univariate mensural differences were found among the six groups in both 220 sexes (Tables 3 and 4). The number of significant differences was highest when $A$. "prasinus"

221 caeruleogularis was compared with $A$. " $p$." prasinus to the north and west (8 differences) and $A$.

222 "p." albivitta to the south and east (11 differences; Table 4). After multiple-test correction

223 (which only affected A. " $p$." cyanolaemus comparisons in Table 4), the fewest differences

224 occurred when $A$. " $p$." cyanoleamus was compared with $A$. " p. " albivitta to the north (3

225 differences) and $A$. " $p$." atrogularis to the south (2 differences), although small sample sizes

226 were likely to be at least partially responsible for this. I included a pairwise comparison between

227 A. "p." albivitta and A. "p." atrogularis because of the uncertain taxonomic status of

228 (major/minor group or species/subspecies; Table 1), and small sample sizes available for, $A$. " $p$."

229 cyanolaemus. Intermediate levels of univariate differences occurred between $A$. "p." prasinus

230 and $A$. " $p$." wagleri (7 differences) and A. " $p$." albivitta and $A$. " $p$." atrogularis (6 differences).

231 Wingtip, bill width, and tarsometatarsus showed the fewest significant differences between

232 groups, whereas wing chord and tail lengths showed the most (Table 4). A pronounced large-

233 small-large pattern was revealed among A. "p." prasinus-caeruleogularis-albivitta (Tables 3 and

234 4). The characteristics exhibiting significant differences between taxon pairs varied among pairs

235 and, in most cases, between sexes (Table 4). In other words, significant mensural differences

236 were decidedly inconsistent between groups. 
238 principal components analyses (PCA). Two analyses were performed. For each sex, all

239 individuals of all groups were run through a single analysis, and the first two principal

240 components (PC1 and PC2) were extracted from the variance-covariance matrix of the log-

241 transformed data. PC1 and PC2 explained $45.0 \%$ and $32.4 \%$ of the variance among males and

$24248.0 \%$ and $31.1 \%$ among females, respectively. For each of the two sex-specific analyses,

243 principal components scores were generated for each individual on PC1 and PC2, and these

244 individual scores were then compared between the major subspecific groups using $t$-tests. These

245 tests were done to determine whether, on a multivariate basis, morphometric differences between

246 taxon pairs were as heterogeneous as suggested by univariate analyses (Tables 3 and 4). Results

247 suggest that they were; again, differences between groups varied in an unpredicatable manner

248 between the sexes and between the two independent multivariate dimensions (PC1 and PC2;

249 Table 5). Of the multivariate pairwise comparisons, only A. "prasinus" albivitta-cyanolaemus

250 showed no significant differences (Table 5), although several univariate differences were found

251 (Table 4). These results may reflect the small sample size in $A$. “p.” cyanolaemus. After

252 multiple-test correction, contrasts within the South American forms (the last three rows in Table

253 5) yielded no significant differences at the table-wide level. Again, while smaller sample sizes

254 likely affected these last results, a "cookie-cutter" effect is not apparent among the major

255 subspecific groups of the $A$. "prasinus" complex, either in univariate or in multivariate

256 morphometric space (Tables 4 and 5).

257 The major, color-based subspecific groups of $A$. "prasinus" do show considerable

258 morphometric differences between them, but are these differences just an expected result from

259 changes of size with latitude under Bergmann's rule (Mayr, 1963) or otherwise geographically 
260 driven? Variation in the two sex-specific principal components was examined in two multiple

261 regressions for each sex (PC1 \& PC2) against the variables latitude and longitude. Neither

262 regression was significant in males, but both were in females $(F>4.0, P<0.02)$. However, only

263 a small proportion of female variation was explained by latitude and longitude, $4 \%$ for PC1 $\left(R^{2}=\right.$

$2640.04)$ and $6 \%$ for PC2 $\left(R^{2}=0.06\right)$. Thus, geography has a small but significant influence in 5 of

265 the 11 differences denoted in Table 5, perhaps contributing to the higher significance levels

266 found in females there. Finally, in considering the individual effects of these two geographic

267 variables, stepwise multiple regression showed that only longitude was significantly associated

268 with $\mathrm{PC} 1$ in females $\left(F=7.56, P=0.007, R^{2}=0.039\right)$; neither variable by itself was significantly

269 associated with PC2. Thus, there is no evidence that Bergmann's rule is affecting this complex as 270 a whole.

271 Hybridization.-Because members of the genus are known to wander rather widely

272 during the nonbreeding season, the opportunity for gene flow does exist between these largely

273 allopatrically breeding groups. Among the six major subgroups I examined there are

274 theoretically five pairwise instances of possible gene flow between any two of the groups,

275 particularly across some of the narrower zones of separation, A. "prasinus" prasinus-wagleri

276 (Oaxaca, Mexico), A. "p." caeruleogularis-albivitta (in W Colombia), A. "p." albivitta-

277 cyanolaemus (Ecuador), and A. "p." cyanolaemus-atrogularis (Peru); the fifth, prasinus-

278 caeruleogularis (in Nicaragua), is a larger distance, on the order of about $240 \mathrm{~km}$. Note that

279 closest approach distances are not accurate in Fig. 2, which is based on the specimens I

280 examined; ranges given by other sources (e.g., Haffer, 1974; Hilty \& Brown, 1986; Binford,

281 1989; Howell \& Webb, 1995; Short \& Horne, 2001; Ridgely \& Greenfield, 2001; Restall,

282 Rodner \& Lentino, 2006; Schulenberg et al., 2007) include more records (including sight 
283 records) and are more accurate.

284 Specimens were examined carefully for phenotypic evidence (i.e., intermediate

285 phenotypes in plumage and bill coloration) of hybridization between these major groups, but it

286 was found to occur in just one of these pairwise comparisons: between $A$. "prasinus"

287 cyanolaemus and A. "p." atrogularis in Peru. Four specimens representing possible $\mathrm{F}_{1}$ hybrids

288 (due to intermediacy of characters) were found; one from La Libertad, Utcubamba (25 October

289 1979, D. Wiedenfeld, LSUMNS 92029; Fig. 3), and three from La Lejía in NE Peru (11 \& 19

290 March, 16 April 1925, H. Watkins, AMNH 234533, 234532, and 234535). All four specimens

291 show obvious intergradation between these two taxa, particularly in bill coloration (see Fig. 3

292 and Haffer, 1974, figure 16.8), and all four are males (these individuals were not included in the

293 morphometric analyses). In addition, there are another five specimens that seem to show

294 evidence of intergradation to a lesser degree, two females that are phenotypically mostly $A$. " $p$."

295 cyanolaemus (both H. Watkins: La Lejía, 19 March 1925, AMNH 234534; and Uscho, Dept.

296 Amazonas, 3 October 1925, AMNH 234531), and three males that are phenotypically $A$. “p."

297 atrogularis but seem to have some $A$. “p." cyanolaemus influence (e.g., primaries edged in

298 russet). These latter three birds are from three localities: Divisoria, Cordillera Azul, Dept.

299 Huanuco (17 August 1967, J. P. O’Neill, LSUMNS 62227), Huanhuachayo, Dept. Ayacucho (6

300 May 1971, J. P. O’Neill, LSUMNS 69410), and Abra Divisiona, Dept. Loreto (14 Aug 1977, J.

301 W. Eley, LSUMNS 84550). It is of interest that this evidence of hybridization occurs between

302 the subspecific pair with the fewest morphometric differences (Table 4) and close genetic

303 affinity (Puebla-Olivares et al., 2008).

304 Morphometrics and hybridization in a genetic context.-While divergent selection should

305 produce phenotypic differences between species, this observation makes predictions neither in 
306 direction nor degree as far as morphometrics are concerned (i.e., it only predicts accumulating

307 differences). Nevertheless, where differences occur between groups on a phylogeny, and the

308 genetic distances involved, might be of further aid in inferring species limits - qualified, of

309 course, by the many known ways in which mtDNA can be misleading about species limits

310 (Avise \& Wollenberg, 1997; Irwin, 2002; Funk \& Omland, 2003; Degnan \& Rosenberg, 2006;

311 Cheviron \& Brumfield, 2009; Galtier et al., 2009; Ribeiro et al., 2011; Toews \& Brelsford, 2012;

312 Pavlova et al., 2013; Peters et al., 2014; Dolman \& Joseph, 2015; Morales et al., 2015). The

313 mtDNA topology of the phylogenetic relationships among the six major subspecific groups is

314 given in Fig. 4 (after Puebla-Olivares et al., 2008). To examine the results of my study in relation

315 to what is presently known about relationships among and genetic distances between the groups

316 examined, I downloaded the mtDNA data of Puebla-Olivares et al. (2008) from GenBank,

317 concatenated and aligned the sequences using Geneious (ver. 7.1; Kearse et al., 2012), and

318 calculated genetic distances between the groups for which I made pairwise comparisons using

319 MEGA (ver. 6; Tamura et al., 2004 \& 2013). Three of these groups are not monophyletic in their

320 mtDNA (not uncommon; see Funk \& Omland, 2003), but I treated the haplotypes of $A$. " $p$."

321 atrogularis that have introgressed into $A$. " $p$." albivitta (see discussion below) as $A$. " $p$."

322 atrogularis for the calculation of genetic distances.

323 Phenotypic evidence of hybridization occurs only between the most closely related pair

324 on this tree, but the presence of $A$. " $p$." atrogularis mtDNA in birds that are phenotypically $A$.

325 " $p$." albivitta with no outward evidence of hybrid characteristics indicate that gene flow can

326 occur between groups that are on average $4.2 \%$ divergent (Fig. 4, bottom clade). Contrasting the

327 number of morphometric differences that have accumulated between the pairwise comparisons

328 of major groups that might hybridize due to proximity (Table 4, excluding albivitta-atrogularis) 
329 with genetic distance reveals a positive correlation (linear regression, $F=6.07, P=0.04, R^{2}=$ $330 \quad 0.67$; Fig. 5).

331

332

333

334 335

\section{DISCUSSION}

My results show that a complex array of morphometric similarities and dissimilarities occur between the major subspecific groups of $A$. "prasinus." Moreover, these variations differ between the sexes. The morphometric data (Tables 3, 4, and 5) clearly show that these taxa are not simply "cookie-cutter" renditions of a green toucanet bearing different head and bill colors. It might be argued that morphological change among the major subspecific groups of $A$. "prasinus" are to be expected: that Bergmann's rule of increased body size with latitude (and elevation; Mayr 1963) would apply to populations of Aulacorhynchus "prasinus" and predispose this examination to finding morphometric differences. Analyses showed no association between male principal components and either latitude or longitude. Further, while female principal components showed a small but significant effect from latitude and longitude, only longitude by itself showed a significant association with PC1, leaving no evidence for Bergmann's rule operating among these taxa as a group. The absence of any geographic effect in males suggests that some other factor, perhaps sexual selection, overcomes the relatively small geographic effect that otherwise occurs in females.

Another possibility is that differences occur not due to genetic disjunctions among locally adapted lineages, but rather to environmental variables affecting development (e.g., James, 1983 1991; West-Eberhard, 2003). If we consider these allopatric forms as a series of natural experiments in differentiation, I suggest that we can consider group-specific morphological evolutionary adaptation as a more likely basis for the observed differences than the possibility of developmental plasticity (although the latter is itself subject to selection; West-Eberhard, 2003), 
352 especially because they are coupled with color changes that are not attributable to developmental

353 plasticity. Several clear patterns emerge from the data to suggest that a simple change in

354 environment is not the cause of the morphological differences occurring among these major

355 groups. These patterns include sexually different morphometric changes between groups (Table

356 4), a large-small-large pattern going from northern Middle America to South America (Table 4),

357 and discordant changes between PC1 and PC2 (Table 5). Nor are the differences among them

358 simply differences in size, as Bergmann's rule would predict; indeed there is a minimal influence

359 of geography alone (latitude and longitude; (Tables 4 and 5). If between-group differences were

360 driven by developmental plasticity, I would expect more evidence of underlying predictable

361 patterns, such as sexually similar responses. Instead, heterogeneity is the hallmark of the

362 differences observed, and ecological adaptation is (hypothetically) a reasonable explanation (see

363 also Mayr, 1963; Price, 2008).

364 Thus, in A. prasinus sensu lato we have complex morphometric changes occurring in

365 conjunction with a series of additional complex phenotypic changes, for example: paedomorphic

366 basal bill encrustations retained and enhanced in adult $A$. "prasinus" wagleri (an important

367 character that alone among these examples is not simply one of color); chestnut coloration in the

368 bill of $A$. " $p$." albivitta; changes in coloration at the base of the bill among the groups, and a

369 double leapfrog pattern in throat colors (light-dark-light-dark; Fig. 1). Concordant shifts in suites

370 of mensural and other morphological characters are precisely what we would predict to occur

371 between individuals representing genetically disjunct, locally adapted gene pools. Consequently,

372 this evidence suggests that this is what they are, and at these levels of morphological

373 differentiation (morphometrics, coloration, and pattern) we would usually consider these groups

374 to be full biological species. But that conclusion does not include all of the evidence available. 
Haffer (1974), who measured 66 A. prasinus (sensu lato), treated all forms as subspecies.

376 Given evidence of hybridization in two cases in the $A$. "prasinus" complex, he concluded that

377 differences would probably not prevent interbreeding; he thus retained the post-Peters (1948)

378 taxonomy for this group. The evidence of intergradation occurs between $A$. " $p$." atrogularis and

379 A. "p." cyanolaemus in Peru (a dataset that I have expanded upon above) and seemingly rather

380 widespread intergradation among A. "p. " albivitta forms (A. "p." albivitta, phaeolaemus, and

381 griseigularis). Probably to simplify his survey of the entire family, Haffer (1974) generally

382 treated all subspecies as equivalent in degree of differentiation, not making distinctions between

383 minor and major variants. Thus, his correct observation of apparently pronounced gene flow

384 among $A$. " $p$." albivitta forms may have overshadowed the comparative rarity of gene flow

385 among the major forms.

386 Short \& Horne (2001) also pointed to intergradation among subspecies and noted (p. 326)

387 that "differences in colour of head and of the bill seem ineffective in preventing interbreeding,

388 e.g. in NW South America; allopatric taxa are no more distinctive in features than are the

389 interbreeding forms (the entire complex ought to be studied carefully before any one taxon is

390 elevated to the status of species)." It is likely that the evidence of hybridization discussed by

391 Haffer (1974) and Short \& Horne (2001) formed the basis for Peters' (1948) massive lumping,

392 although he gave no reasoning.

393 Navarro et al. (2001) studied the phenotype of the $A$. "prasinus" complex, examining 247

394 specimens from Middle America and 58 from South America. Unlike my study, they included in

395 their analyses patterns and colors of the head and bill. They sidestepped the issue of

396 hybridization and concluded that there were four species in Middle America (A. wagleri,

397 prasinus, caeruleogularis, and cognatus) and three more in South America (A. lautus, albivitta, 
398 and atrogularis ["nigrogularis" in their abstract is an error]).

399 Puebla-Olivares et al. (2008) provided the first genetic data for the $A$. "prasinus"

400 complex. My conclusions, which I will detail below, are mostly congruent with theirs, but there

401 are also key differences (Table 1). These differences stem mainly from how we choose to

402 interpret the genetic data and morphological diagnosability. For example, Puebla-Olivares et al.

403 (2008) relied heavily on genetic distance, reciprocal monophyly, and inferred gene flow using

404 relatively small population samples and a single locus (mtDNA). Although the evolutionary

405 hypothesis that their data provides for this group is likely to be mostly accurate, the power of

406 these data for determining species limits is not high, particularly in a group in which

407 hybridization has played a pivotal role in determining taxonomy. Moreover, if we set aside

408 genetic distance for a moment, there are other named, allopatric forms that are morphologically

409 diagnosable and reciprocally monophyletic in their data that they did not highlight as being likely

410 species (e.g., the subspecies A. prasinus warneri, volcanius, and chiapensis within prasinus,

411 sensu stricto). Further, Puebla-Olivares et al. (2008) showed two A. "p." albivitta from NE

412 Ecuador in their A. "p." "atrogularis" clade with no discussion (contrast their table 1 locality 22

413 with their figures 1 and 2; $A$. " $p$." albivitta is the form that occurs in NE Ecuador, not $A$. " $p$."

414 atrogularis, given incorrectly in their figure 1 but correctly in their table 1). This is a clear

415 mismatch of morphology and genetics: two individuals that are phenotypically $A$. " $p$." albivitta

416 (catalogued as such and verified by me from photographs) have mtDNA haplotypes more closely

417 related to A. "p." atrogularis and cyanolaemus. (The vouchers are ANSP 185,312 for tissue

4184837 and ANSP 185,311 for tissue 4799; only tissue numbers are given for these birds by

419 Puebla-Olivares et al. [2008].) This produces a paraphyletic $A$. " $p$." albivitta and suggests that

420 there has been historical gene flow between forms that are quite different. 
While these data are important, using them to determine species limits is problematic.

422 And considering morphology, their observation (Puebla-Olivares et al., 2008:47) that the

423 diagnostic morphological attributes of their focal clades "could facilitate reproductive isolation"

424 is unduly optimistic given evidence to the contrary (e.g., their own unremarked $A$. " $p$. " albivitta

425 results and the quote of Short \& Horne [2001] above). Genetic distance is not a reliable indicator

426 of species limits in birds (Price, 2008; Winker, 2009). A better indicator is how the birds

427 themselves interact when in contact (Mayr, 1969; Mayr \& Ashlock, 1991). And when examining

428 gene flow, sample sizes and geographic coverage become critically important (Winker, 2010),

429 especially in groups, such as the A. "prasinus" complex, whose taxonomy has been so affected

430 by evidence of hybridization.

431

Hybridization.-Fortunately, with respect to gene flow we do have larger sample sizes if

432 we use diagnostic morphological attributes as a surrogate (i.e., the plumage and bill

433 characteristics upon which the named forms have been based). Despite what is likely to be ample

434 opportunity for gene flow through dispersal across the five zones of contact or "nearest

435 approach," evidence of hybridization among the major groups in the $A$. "prasinus" complex

436 presently exists in just two cases: between $A$. "prasinus" atrogularis and cyanolaemus

437 (phenotypic only, as detailed above), and in the genetic results of Puebla-Olivares et al. (2008),

438 which showed two $A$. " $p$.” albivitta specimens from NE Ecuador with mtDNA more closely

439 related to $A$. " $p$." cyanolaemus/atrogularis. This latter case suggests that historical crossing may

440 have occurred across this zone, although morphological evidence of this is not yet evident.

441 Aulacorhynchus "prasinus" is uncommon in this region, and the ranges of $A$. " $p$." albivitta and

442 cyanolaemus are not known to come into contact (Ridgely \& Greenfield, 2001; Restall, Rodner

443 \& Lentino, 2006). These two A. “p.” albivitta specimens also demonstrate that phenotypic 
444 evidence of hybridization, which does occur and has been useful in past evaluations in $A$.

445 "prasinus," can be absent despite gene flow (but even nuclear genomic evidence of hybridization

446 can disappear over a few generations of backcrossing; Lavretsky et al., 2016).

447 From this dataset, therefore, we know that hybridization in toucanets can be visible and

448 invisible, the latter probably after repeated backcrossings to one parent taxon. We might,

449 however, consider the visible hybrids to be roughly indicative of a hybridization rate. Current

450 evidence thus suggests that hybridization between $A$. " $p$." albivitta and cyanolaemus is rare. In

451 the case of $A$. " $p$." cyanolaemus and atrogularis, however, my results expand the scope of

452 hybridization recognized, both in number of possible $F_{1}$ specimens (those most intermediate in

453 characters) and in the broader distribution of specimens likely exhibiting intergradation (and note

454 that it is bi-directional). The fact that all four putative $F_{1}$ specimens are males suggests the

455 possibility that the two forms are sufficiently divergent that genetic incompatibilities are

456 preventing viability of the heterogametic sex, which is the female in birds (Haldane's rule; Price,

457 2008). However, this is not a significant departure from the sex ratio of the rest of the $A$.

458 "prasinus" sample I examined ( $P=0.13$, Fisher's exact test), and the two forms are not very

459 divergent genetically in mtDNA $(<1 \%$; Fig. 4 and Puebla-Olivares et al., 2008). The matrilineal

460 passage of $A$. "p." cyanolaemus/atrogularis mtDNA into $A$. "p." albivitta in NE Ecuador

461 (Puebla-Olivares et al., 2008) also suggests that Haldane's rule is not operating among major

462 subspecific groups in South America. In the case of $A$. " $p$." cyanolaemus and $A$. " $p$."

463 atrogularis, hybrids and intergrades represented a substantial percentage of the specimens I was

464 able to examine of these taxa (as many as 10 specimens, with remaining sample sizes of 19 each

465 of cyanolaemus and atrogularis). Given the small sample, it remains unclear whether this

466 reflects the true incidence of hybrids between these taxa, but given present evidence it is 
467 substantial.

468 Species limits.-Despite considerable combined evidence from coloration,

469 morphometrics, and mtDNA data, comprehensive and accurate species limits for this group

470 remain elusive, no matter what species concept one chooses to use. Using the biological species

471 concept, I suggest that consideration of all of the available evidence indicates that we should

472 recognize five species in the A. "prasinus" complex (A. wagleri, prasinus, caeruleogularis,

473 albivitta, and atrogularis), each with any associated named subspecies (Appendix). Further study

474 could raise this number (e.g., by splitting A. atrogularis cyanolaemus from atrogularis again).

475 Under a phylogenetic species concept (PSC), one could probably raise every allopatric

476 population in $A$. "prasinus" to the species level, resulting in at least 12 taxa using morphology

477 alone. So how many species of toucanets are there in the $A$. "prasinus" complex?

478 Historically, evidence of hybridization has often driven taxonomic decisions under the

479 biological species concept (BSC), as has apparently occurred in this case. My interpretation of

480 the taxonomic history of Aulacorhynchus "prasinus" is that evidence of hybridization and

481 intergradation between named forms (among forms of the $A$. " $p$." albivitta group and between $A$.

482 "p." albivitta and cyanolaemus) caused all named forms to be lumped together as one species

483 (Peters, 1948). But hybridization is not uncommon between full species (Grant \& Grant, 1992),

484 and avian taxonomists have used a working definition of the BSC that recognizes this (e.g.,

485 Short, 1969; Johnson, Remsen \& Cicero 1999; Winker et al., 2007). Gene flow, reproductive

486 isolating mechanisms, and lineage reticulation remain fundamentally important evolutionary

487 phenomena affecting species diversity and the process of evolutionary divergence, and thus they

488 require consideration. Effective lineage reticulation requires that hybrid offspring have equal or

489 greater fitness than offspring of pure parental forms. Also, gene flow must occur frequently 
490 enough to overcome the differentiating selective factors likely to be operating on largely

491 allopatric populations (and this relationship is nonlinear; see Winker, 2010 for discussion). The

492 more differences there are between populations in morphology, the more differences there are

493 likely to be in selective factors operating on these populations and the more difficult effective

494 gene flow is likely to be between populations; at larger scales this results in the general

495 correlation between morphological difference and reproductive isolation (Mayr, 1963; Price, 496 2008).

Classic systematics and taxonomy (Mayr, 1969; Mayr \& Ashlock, 1991) uses a

498 comparative approach to determine species limits among allopatric taxa, examining what occurs 499 at contact zones (if available) and/or what occurs in similar cases in closely related taxa. In

500 previous work on $A$. "prasinus" taxonomy I do not think enough credit has been given to the 501 dispersal abilities of these birds. And yet despite that ability there is a lack of evidence for gene

502 flow (using phenotype as an indicator) between five of the major subspecific groups ( $A$.

503

prasinus-wagleri, prasinus-caeruleogularis, caeruleogularis-albivitta, albivitta-cyanolaemus).

504 For example, in south-central Mexico (Oaxaca), A. prasinus and A. wagleri breed within about

$505100 \mathrm{~km}$ of each other, a distance that A. prasinus individuals appear to move routinely away

506 from their breeding areas, e.g., at the base of the Yucatan Peninsula (e.g., Land, 1970; Jones,

507 2003), which does not seem unusual for an arboreal frugivore (see also discussions in O'Neill \&

508 Gardner, 1974, and Navarro et al., 2001). Hybridization per se is not sufficient evidence for

509 conspecificity, and in this group I find the lack of hybrids at most zones of potential crossing of

510 major subspecific groups to be more compelling in the determination of species limits than its

511 clear and seemingly routine presence at one - particularly in light of the repeated evidence of

512 varying suites of morphological characters changing abruptly across these zones. However, I do 
513 consider that the apparent frequency of hybridization between $A$. atrogularis cyanolaemus and $A$.

514 a. atrogularis warrants a conservative approach to their separation at the species level, and thus I

515 do not recommend doing so without more evidence. In short, morphologically there is no

516 evidence for hybridization between five of the major subspecific groups, despite likely

517 opportunity, especially in northern Middle America. This is coupled with pronounced

518 morphometric differences between these groups, suggesting group-specific ecological adaptation

519 in addition to whatever social selection factors have likely caused the rather dramatic head and

520 bill color differences (Fig. 1, Table 2).

521 The populational processes of lineage divergence and the hierarchical nature of

522 differentiation that accrues as gene flow decreases and divergent selection produces increasingly

523 different phenotypes (anagenesis) have produced gradations of differentiation in the genus

524 Aulacorhynchus. This is seen from population-level differences of little significance (e.g., among

525 some questionably recognizable subspecies; see Appendix), to diagnosable isolated populations

526 within biological species, to full biological species, to a recognizable subgeneric group (members

527 of $A$. "prasinus" sensu lato). Genetic data also support this subgeneric group (Puebla-Olivares et

528 al., 2008), and the name Ramphoxanthus, which is particularly fitting (i.e., yellow-bills), is

529 available for it (Bonaparte, 1854). This group diverged from other members of the genus during

530 the Miocene (approximately 6-9 million years ago; Bonaccorso \& Guayasamin, 2013). Within

531 the five groups comprising $A$. "prasinus" that I consider full biological species (A. wagleri,

532 prasinus, caeruleogularis, albivitta, and atrogularis) there are a number of diagnosable

533 subspecific taxa that are clearly evolutionarily significant units, and some, being $100 \%$

534 diagnosable, could be called phylogenetic species (e.g., A. p. warneri, A. c. cognatus, A. albivitta

535 lautus). These, however, do not represent major phenotypic differences, and I consider this 
536 continued lumping to be warranted given present evidence, which includes hybridization and

537 intergradation between other subspecies with similar degrees of differentiation within the major

538 subspecific $A$. “prasinus" groups (e.g., A. p. prasinus-virescens, A. albivitta phaeolaemus-

539 griseigularis; Short \& Horne, 2001, and personal observation).

540 Voice has not diverged among these five groups as much as it has in other species in the

541 genus (Schwartz, 1972; Short \& Horne, 2001). Indeed, Short \& Horne (2001:327) related that

542 "Calls of forms in Peru, Venezuela, Panama, Costa Rica and Mexico are much alike..."

543 However, more work is warranted in this area. For example, $A$. wagleri has a slower pace to its

544 vocalizations than $A$. prasinus (from www.xeno-canto.org, 4 A. wagleri average 1.85 calls/sec

545 while 6 A. prasinus average 2.13 calls/sec; XC 274798, 219401-2, and 177515 vs. XC 96724 ,

$546256673,256311,233097$, and 138132-3). Other differences may be apparent with increased

547 sample sizes.

548 Considering my suggested taxonomy (Appendix) in relation to the mtDNA tree of

549 Puebla-Olivares et al. (2008), there are two paraphyletic species (Fig. 4). First, A. albivitta is

550 paraphyletic with respect to $A$. atrogularis-cyanolaemus. Second, my treatment of $A$.

551 caeruleogularis is paraphyletic with respect to A. prasinus and A. wagleri because it includes $A$.

552 " $p$. ." cognatus; that has been the norm since its description, only Navarro et al. (2001) and

553 Puebla-Olivares et al. (2008) have treated it as a full species thus far. Paraphyletic species are not

554 uncommon (Funk \& Omland, 2003; Oyler-McCance, St. John \& Quinn, 2010), but there is

555 clearly work remaining to be done on species limits in this complex, especially in South

556 America. For example, the distributions of $A$. atrogularis cyanolaemus, $A$. a. atrogularis, and the

557 hybrid zone between them warrant further study, as does the apparently rare instance of crossing

558 between A. albivitta and A. atrogularis cyanolaemus in Ecuador (mtDNA evidence of Puebla- 
559 Olivares et al,. 2008). Also, the relationship between A. c. caeruleogularis and A. c. cognatus in

560 Panama bears further investigation; they are phenotypically relatively similar (Short \& Horne,

$5612001: 325$ also noted their close resemblance) in contrast to, e.g., A. a. atrogularis and

562 cyanolaemus. Larger sample sizes, more loci, coverage of hybrid zones, and continued

563 recognition that there are relatively major and minor phenotypic variants among these named

564 taxa will be needed to finally and fully resolve species limits in this group.

565

566

567

568

569

570

571

572

573

574

575

576

577

578

579

580

581

582

583

\section{ACKNOWLEDGMENTS}

I thank the curators and staff of the following collections for their kindness during visits or for loaning material: Louisiana State University Museum of Natural Science (LSUMNS), American Museum of Natural History (AMNH), Southwestern College (SWC), National Museum of Natural History (USNM), Carnegie Museum (CM), Field Museum of Natural History (FMNH), Moore Laboratory of Zoology (MLZ), the Academy of Natural Sciences of Philadelphia (ANSP), Museo de Zoologia, Facultad de Ciencias, Universidad Nacional Autonoma de México (MZFC), and the Colección Nacional de Aves, Instituto de Biología, Universidad Nacional Autonoma de México (CNAV). John O'Neill, Matthew Miller, Alexandre Aleixo, and several anonymous reviewers gave helpful comments on previous drafts of the manuscript. Rob Faucet and Max Thompson helped with localities. Nate Rice provided photographs of the ANSP vouchers of $A$. albivitta with $A$. atrogularis/cyanolaemus haplotypes in Puebla-Olivares et al. (2008). Finally, I wish to thank Kristin Williams for her excellent painting of the $A$. "prasinus" group.

\section{LITERATURE CITED}

American Ornithologists' Union (AOU). 1983. Check-list of North American birds (6 $\left.6^{\text {th }} \mathrm{ed}\right)$. Lawrence, Kansas: American Ornithologists' Union.

American Ornithologists' Union (AOU). 1998. Check-list of North American birds ( $7^{\text {th }}$ ed). 
584 Washington, D. C.: American Ornithologists' Union.

585

586

587

588

589

590

591

592

593

594

595

596

597

598

599

600

601

602

603

604

605

606

607

608

609

610

611

612

613

614

615

616

617

618

619

620

621

622

623

624

625

626

627

628

629
Avise J, Wollenberg K. 1997. Phylogenetics and the origin of species. Proceedings of the National Academy of Sciences USA 94:7748-7755.

Baldwin SP, Oberholser HC, Worley LG. 1931. Measurements of birds. Scientific Publications of the Cleveland Museum of Natural History 2:1-165.

Bangs, O. 1898. On some birds from the Sierra Nevada de Santa Marta, Colombia. Proceedings of the Biological Society of Washington 12:171-182.

Benjamini Y, Hochberg Y. 1995. Controlling the false discovery rate: A practical and powerful approach to multiple testing. Journal of the Royal Statistical Society B 57:289-300.

Binford LC. 1989. A distributional survey of the birds of the Mexican state of Oaxaca. Ornithological Monographs 43:1-418.

Boissonneau M. 1840. Oiseaux nouveaux de Santa-Fé de Bogota. Revue Zoologique 1840:6671.

Bonaparte CL. 1854. Conspectus volucrum zygodactylorum. Ateneo Italiano 1(8):116-129.

Bonaccorso E, Guayasamin JM, Peterson AT, Navarro-Sigüenza AG. 2011. Molecular phylogeny and systemtatics of Neotropical toucanets in the genus Aulacorhynchus. Zoologica Scripta 40:336-349.

Bonaccorso E, Guayasamin JM. 2013. On the origin of Pantepui montane biotas: A perspective based on the phylogeny of Aulacorhynchus toucanets. PLoS ONE 8:e67321.

Brodkorb P. 1940. New birds from southern Mexico. Auk 57:542-549.

Brabourne L, Chubb C. 1912. The birds of South America. Vol. I. London: Taylor and Francis.

Carriker MA Jr. 1933. Descriptions of new birds from Peru, with notes on other little-known species. Proceedings of the Academy of Natural Sciences of Philadelphia 85:1-38.

Chapman FM. 1915. Diagnoses of apparently new Colombian birds. IV. Bulletin of the American Museum of Natural History 34:635-662.

Chapman FM. 1917. The distribution of bird-life in Colombia: A contribution to a biological survey of South America. Bulletin of the American Museum of Natural History 36:1-729.

Cheviron ZA, Brumfield RT. 2009. Migration-selection balance and local adaptation of mitochondrial haplotypes in rufous-collared sparrows (Zonotrichia capensis) along an elevational gradient. Evolution 63: 1593-1605. 
630 Cory CB. 1919. Catalogue of birds of the Americas. Part II, No. 2. Field Museum of Natural

631

632

633

634

635

636

637

638

639

640

641

642

643

644

645

646

647

648

649

650

651

652

653

654

655

656

657

658

659

660

661

662

663

664

665

666

667

668

669

670

671

672

673

674

675

History Zoological Series 13:317-607.

Degnan JH, Rosenberg NA. 2006. Discordance of species trees with their most likely gene trees. PLoS Genetics 2:e68.

del Hoyo J, Collar NJ. 2014. HBW and BirdLife International Illustrated Checklist of the Birds of the World, Volume 1, Non-passerines. Barcelona: Lynx Edicions.

"D. W. M." 1853. Proceedings of the Zoological Society [being a report of two meetings in February of this year]. Zoologist 1853:3860-3861.

Dickey DR, van Rossem AJ. 1930. Geographic variation in Aulacorhynchus prasinus (Gould). Ibis 1930:48-55.

Dickinson EC, and Remsen JV Jr. (Eds.) 2013. The Howard and Moore Complete Checklist of the Birds of the World, $4^{\text {th }}$ ed., Volume 1 Non-Passerines. Eastbourne, U. K.: Aves Press.

Dolman G, Joseph L. 2015. Evolutionary history of birds across southern Australia: structure, history and taxonomic implications of mitochondrial DNA diversity in an ecologically diverse suite of species. Ети 115:35-48.

Funk DJ, Omland K. 2003. Species-level paraphyly and polyphyly: Frequency, causes, and consequences, with insights from animal mitochondrial DNA. Annual Review of Ecology Evolution and Systematics 34: 397-423.

Galtier N, Nabholz B, Glemin S, Hurst GDD. 2009. Mitochondrial DNA as a marker of molecular diversity: a reappraisal. Molecular Ecology 18: 4541-4550.

Gould J. 1833. A Monograph of the Ramphastidae, or Family of Toucans (part 1). London: The author.

Gould J. 1841-47. Monographie der Ramphastiden. Nuremburg.

Gould J. 1854. Description of a new species of Aulcorhamphus. Proceedings of the Zoological Society of London 1853:45.

Gould J. 1866. Description of a new species of toucan belonging to the genus Aulacoramphus. Proceedings of the Zoological Socety of London 1866:24.

Gould J. 1874. On three new species of toucans pertaining to the genus Aulacorhamphus. Annals \& Magazine of Natural History (4) 14:183-4.

Grant PR, Grant BP. 1992. Hybridization in bird species. Science 256:193-197.

Griscom L. 1924. Descriptions of new birds from Panama and Costa Rica. American Museum 
676

677

678

679

680

681

682

683

684

685

686

687

688

689

690

691

692

693

694

695

696

697

698

699

700

701

702

703

704

705

706

707

708

709

710

711

712

713

714

715

716

717

718

719

Novitates 141:1-12.

Haffer J. 1974. Avian speciation in tropical South America. Publications of the Nuttall Ornithological Club 14:1-390.

Hellmayr CE. 1911. A contribution to the ornithology of western Colombia. Proceedings of the Zoological Society of London 1911:1084-1213.

Hilty SL, Brown WL. 1986. A guide to the birds of Colombia. Princeton, New Jersey: Princeton University Press.

Howell SNG, Webb S. 1995. A guide to the birds of Mexico and northern Central America. Oxford: Oxford University Press.

Irwin D J. 2002. Phylogeographic breaks without geographic barriers to gene flow. Evolution 56: 2383-2394.

James FC. 1983. Environmental component of morphological differentiation in birds. Science 221:184-186.

James FC. 1991. Complementary descriptive and experimental studies of clinal variation in birds. American Zoologist 31:694-706.

Johnson NK, Remsen JV Jr, Cicero C. 1999. Resolution of the debate over species concepts in ornithology: A new comprehensive biologic species concept. Pages 1470-1482 in Proceedings of the 22nd International Ornithological Congress (Adams NJ, Slotow RH, eds.). Johannesburg:

BirdLife South Africa.

Jones HL. 2003. Birds of Belize. Austin: University of Texas Press.

Kearse M, Moir R, Wilson A, Stones-Havas S, Cheung M, Sturrock S, Buxton S, Cooper A, Markowitz S, Duran C, Thierer T, Ashton B, Meintjes P, Drummond A. 2012. Geneious Basic: an integrated and extendable desktop software platform for the organization and analysis of sequence data. Bioinformatics 28:1647-1649.

Mayr E. 1963. Animal Species and Evolution. Cambridge, Massachusetts: Belknap Press.

Mayr E. 1969. Principles of Systematic Zoology. New York: McGraw-Hill Book Company.

Mayr E, Ashlock PD. 1991. Principles of Systematic Zoology (2nd ed). New York: McGrawHill, Inc.

Land H. 1970. Birds of Guatemala. Wynnewood, Pennsylvania: Livingston Publishing Company. 
720

721

722

723

724

725

726

727

728

729

730

731

732

733

734

735

736

737

738

739

740

741

742

743

744

745

746

747

748

749

750

751

752

753

754

755

756

757

758

759

760

761

762

763

764

765

Mallet J. 2007. Subspecies, semispecies, superspecies. In Levin, S.A. (ed.) Encyclopedia of Biodiversity. Elsevier Inc., Oxford. Online update1, pp. 1-5.

Morales HE, Pavlova A, Joseph L, Sunnucks P. 2015. Positive and purifying selection in mitochondrial genomes of a bird with mitonuclear discordance. Molecular Ecology 24:28202837.

Lavretsky P, Peters JL, Bahn V, Kulikova I, Zhuravlev YN, Wilson R, Barger C, Winker K, Gurney K, Clark B, Breault A, Slattery S, McCracken KG. 2016. Becoming pure: identifying generational classes of admixed individuals within lesser an greater scaup populations. Molecular Ecology 25:661-674.

Monroe BL Jr. 1968. A distributional survey of the birds of Honduras. Ornithological Monographs 7:1-458.

Navarro S AG, Peterson AT, López-Medrano E, Benítez-Díaz H. 2001. Species limits in Mesoamerican Aulacorhynchus toucanets. Wilson Bulletin 113:363-372.

Nelson EW. 1912. Descriptions of new genera, species and subspecies of birds from Panama, Colombia and Ecuador. Smithsonian Miscellaneous Collections 60:1-26.

Olson SL. 1997. [Review of] John Gould the Bird Man. Auk 114:540-541.

O’Neill JP, Gardner AL. 1974. Rediscovery of Aulacorhynchus dimidiatus (Ridgway). Auk 91:700-704.

Oyler-McCance SJ, St. John J, Quinn TW. 2010. Rapid evolution in lekking grouse:

Implications for taxonomic definitions. Ornithological Monographs 67:114-122.

Pavlova A, Amos JN, Joseph L, Loynes K, Austin J, Keogh JS, Stone GN, Nicholls JA, Sunnucks P. 2013. Perched at the mito-nuclear crossroads: divergent mitochondrial lineages correlate with environment in the face of ongoing nuclear gene flow in an Australian bird. Evolution 67:3412-3428.

Peters JL. 1948. Check-list of birds of the world, Vol. VI. Cambridge, Massachusetts: Harvard University Press.

Peters J L, Winker K, Millam KC, Lavretsky P, Kulikova I, Wilson RE, Zhuravlev YN, McCracken KG. 2014. Mito-nuclear discord in six congeneric lineages of Holarctic ducks (genus Anas). Molecular Ecology 23:2961-2974.

Price, T. 2008. Speciation in Birds. Greenwood Village, Colorado: Roberts and Company.

Puebla-Olivares F, Bonaccorso E, Espinosa de los Monteros A, Omland KE, LlorenteBosquets JE, Peterson AT, Navarro-Sigüenza AG. 2008. Speciation in the emerald toucanet 
766

767

768

769

770

771

772

773

774

775

776

777

778

779

780

781

782

783

784

785

786

787

788

789

790

791

792

793

794

795

796

797

798

799

800

801

802

803

804

805

806

807

808

809

810

811

(Aulacorhynchus prasinus) complex. Auk 125:39-50.

Remsen JV Jr, Areta JI, Cadena CD, Jaramillo A, Nores M, Pacheco JF, Pérez-Emán J, Robbins MB, Stiles FG, Stotz DF, Zimmer KJ. Version 14 April 2016. A classification of the bird species of South America. American Ornithologists' Union.

www.museum.lsu.edu/ Remsen/SACCBaseline.html

Restall R, Rodner C, Lentino M. 2006. Birds of Northern South America: An identification guide. New Haven, Connecticut: Yale University Press.

Ribeiro AM, Lloyd P, Bowie RCK. 2011. A tight balance between natural selection and gene flow in a southern African arid-zone endemic bird. Evolution 65:3499-3514.

Ridgely RS, Greenfield PJ. 2001. The Birds of Ecuador, Vol. II. Ithaca, New York: Comstock Publishing Associates.

Ridgway R. 1886. Descriptions of some new species of birds supposed to be from the interior of Venezuela. Proceedings of the U. S. National Museum 9:92-94.

Ridgway R. 1912. Descriptions of some new species and subspecies of birds from tropical America. Proceedings of the Biological Society of Washington 25:87-92.

Ridgway R. 1914. The Birds of North and Middle America, Part VI. Bulletin of the U.S. National Museum 50(6):1-882.

Salvin O, Godman FD. 1896. Biologia Centrali-Americana, Aves. Vol. II. London: Taylor and Francis.

Schwartz P. 1972. On the taxonomic rank of the Yellow-billed Toucanet. Boletin Sociedad Venezolana Ciencias Naturales 29:459-476.

Schulenberg TA, Stotz DF, Lane DF, O’Neill JP, Parker TA III. 2007. Birds of Peru. Princeton, New Jersey: Princeton University Press.

Sclater PL. 1891. Family Rhamphastidae, pp. 122-160 in Catalogue of the Birds in the British Museum, Volume XIX. London: British Museum (Natural History).

Short LL. 1969. Taxonomic aspects of avian hybridization. Auk 86:84-105.

Short LL., Horne JFM. 2001. Toucans, barbets, and honeyguides. Oxford: Oxford University Press.

Short LL., Horne JFM. 2002. Family Ramphastidae (toucans). Pp. 220-272 in Handbook of the Birds of the World, Volume 7 (del Hoyo J, Elliott A, Sargatal J, eds.). Barcelona: Lynx Edicions.

Sibley CG, Monroe BL Jr. 1990. Distribution and taxonomy of birds of the world. New Haven, 
812 Connecticut: Yale University Press.

813

814 Sokal RR., Rohlf FJ. 1995. Biometry ( $3^{r d}$ ed). New York: W. H. Freeman and Company.

815

816

817

Tamura K, Nei M, Kumar 2. 2004. Prospects for inferring very large phylogenies by using the 81811035.

819

Tamura K, Stecher G, Peterson D, Filipski A, Kumar S. 2013. MEGA6: Molecular

Evolutionary Genetics Analysis version 6.0. Molecular Biology and Evolution 30:2725-2729.

822

823

824

825

826

827

828

829

830

831

832

833

834

835

836

837

838

839

840

841

842

843

844

845

846

847

848

849

850

851

Toews DP, Brelsford A. 2012. The biogeography of mitochondrial and nuclear discordance in animals. Molecular Ecology 21:3907-3930.

Wetmore A. 1968. The birds of the Republic of Panama. Part 2. Columbidae (pigeons) to Picidae (woodpeckers). Washington, D. C.: Smithsonian Institution Press.

West-Eberhard MJ. 2003. Developmental Plasticity and Evolution. New York: Oxford University Press.

Whitlock MC, Schluter D. 2009. The Analysis of Biological Data. Greenwood Village, Colorado: Roberts and Company Publishers.

Winker K. 2000. A new subspecies of toucanet (Aulacorhynchus prasinus) from Veracruz, Mexico. Ornitología Neotropical 11:253-257.

Winker K. 2009. Reuniting genotype and phenotype in biodiversity research. BioScience 59:657-665.

Winker K. 2010. Subspecies represent geographically partitioned variation, a goldmine of evolutionary biology, and a challenge for conservation. Ornithological Monographs 67:6-23.

Winker K, Rocque D, Braile TM, Pruett CL. 2007. Vainly beating the air: Species concept debates need not impede science and conservation. Ornithological Monographs 63:30-44.

Figure 1. The six major, color-based taxonomic groups of the Aulacorhynchus "prasinus" species complex, from top to bottom: A) wagleri; B) prasinus (nominate prasinus and warneri, the full-bodied bird, are portrayed): C) caeruleogularis; D) albivitta (griseigularis and nominate 
852 albivitta are portrayed); E) cyanolaemus (yellow-tipped bill); and F) atrogularis.

853

854

855 Figure 2. Distributions of the specimens of Aulacorhynchus "prasinus" examined in this study

856 with the focal six major subspecific groups labeled. Neither all specimens in existence nor

857 observation records are included, so ranges are not complete. Red stars indicate evidence of

858 hybridization; the top-most one, in Ecuador, is from the study of Puebla-Olivares et al. (2008).

859

860 Figure 3. An example of a hybrid $A$. “p.” atrogularis $\times$ A. “p.” cyanolaemus. A) a pure A. “p.”

861 cyanolaemus (LSU 87627); B) a hybrid (LSU 92029); and C) a pure A. “p. ” atrogularis (LSU 862 73933).

863

864 Figure 4. The mtDNA topology of the relationships among the six major subspecific groups, 865 following Puebla-Olivares et al. (2008). Taxa labeled with a “(+)” are non-monophyletic in 866 mtDNA. Values between the major subspecific groups are the between-group mean genetic 867 distances between them.

868

869 Figure 5. The relationship between genetic distance (Figure 4) and the accumulation of 870 morphometric differences (Table 4) between the major subspecific groups that might hybridize 871 due to proximity. The positive correlation is that predicted by the processes of anagenesis and 872 speciation. 


\section{Appendix}

874 Suggested taxonomy.-Because I have examined all of the described taxa in the complex,

875 this revision includes subspecies (although quantitative analyses were not undertaken below the

876 level of the six major groups). Given below are species, subspecies, authors of original

877 descriptions, type localities, and notes pertaining to each species. Distribution is not included,

878 because I did not examine all existing specimens and can add little of substance to distributions

879 set forth by the authors cited herein. The species sequence given follows the relationships in the

880 mtDNA tree of Puebla-Olivares et al. (2008) but with the two major clades flipped to better

881 accommodate the group's geographic distribution (as I have also done in Fig. 4).

882

883

Genus Aulacorhynchus (green toucanets), subgenus Ramphoxanthus

884

885 Aulacorhynchus wagleri (Sturm in Gould, 1841:pl. 16 (heft 2, pl. 6)). Wagler's Toucanet.

886 no type loc. [= Guerrero and Oaxaca, Mexico].

887

888 Aulacorhynchus prasinus (Gould, 1833). Northern Emerald Toucanet.

889 A. p. prasinus (Gould, 1833). Mexico [= Valle Real, Oaxaca].

890 A. p. warneri Winker (2000). Volcán San Martín, Sierra de Los Tuxtlas, Veracruz,

$891 \quad$ Mexico.

$892 \quad$ A. p. virescens Ridgway (1912:88). Chasniguas, Honduras.

893 A. p. volcanius Dickey and van Rossem (1930:53). Volcán de San Miguel, Dept. San

894 Miguel, El Salvador.

895 Notes: A. p. stenorhabdus (Dickey and van Rossem, 1930:52) and A. p. chiapensis (Brodkorb, 
896 1940) are considered synonyms of $A$. $p$. virescens; variation among them appears to be clinal 897 (see also Monroe, 1968). Wetmore (1941, notes in USNM) considered chiapensis as "doubtfully 898 separable," but recognized stenorhabdus. See notes under A. albivitta regarding the English 899 common name.

900 Aulacorhynchus caeruleogularis (Gould, 1854:45). Blue-throated Toucanet.

901 A. c. caeruleogularis (Gould, 1854:45). Veragua [, Panama] [= Boquete, Chiriquí; Wetmore $902 \quad 1968: 508]$.

903

A. c. cognatus (Nelson, 1912:4). Mount Pirri (at 5,000 feet altitude) head of Rio Limon, 904 eastern Panama.

905

906

907

908

909

910

911

912

913

914

915 A. a. phaeolaemus Gould (1874:184). Concordia, in Columbia [sic], and Merida, in

916 Venezuela [= Concordia, Antioquia, western Colombia; Hellmayr, 1911:1213].

917 A. a. albivitta (Boissonneau, 1840:70). Santa-Fé de Bogota [, Colombia].

918 Notes: Chapman (1917) inexplicably omitted the occurrence of the species (endemic subsp.

Aulacorhynchus albivitta (Boissonneau, 1840:70). Southern Emerald Toucanet.

Notes: A. c. maxillaris (Griscom, 1924:2) is considered a synonym of A. c. caeruleogularis (cf. Wetmore 1968:509). See Wetmore (1968) for citation of the name caeruleogularis appearing first in the Zoologist in 1853; no description appears there, however, the reference being a report of what occurred at two meetings in February 1853 (“D.W.M.”, 1853). Olson (1997) provided more notes on these occurrences in relation to Gould.

A. a. lautus (Bangs, 1898:173). San Miguel [, Sierra Nevada de Santa Marta], Colombia.

A. a. griseigularis Chapman (1915:639). Santa Elena (alt. 9000 ft.), Cen. Andes,

14 Antioquia, Col. 
919 lautus) in the Santa Marta region. More detailed study is needed to resolve problems in the 920 status, relationship, distributions, and nomenclature of phaeolaemus and griseigularis (see

921 Chapman, 1917; Haffer, 1974). The English name for this species given by Cory (1919:377),

922 White-throated Toucanet, is only appropriate for the subspecies albivitta, and thus is more

923 appropriate at the species level for $A$. prasinus (sensu stricto, though not used there). The other

924 subspecies of albivitta are all grayish or grayish-blue on the throat. Del Hoyo and Collar (2014)

925 suggested Grayish-throated, but this overlooks both white-throated birds and those with blue in

926 the throats. Accordingly, I have suggested more fitting English names for this species and $A$.

927 prasinus.

928

929 Aulacorhynchus atrogularis (Sturm in Gould, 1841:heft 2, pl.2 \& text). Black-throated $930 \quad$ Toucanet.

931 A. a. cyanolaemus (Gould, 1866:24). Loxa [=Loja] in Ecuador.

932 A. a. atrogularis (Sturm in Gould, 1841:heft 2, pl.2 \& text). Andes of Peru

933 [=Chunchamayo, central Peru; Cory, 1919:380).

934 A. a. dimidiatus (Ridgway, 1886:93). No loc.; suggested by O'Neill and Gardner

935 (1974:703) to be along the eastern foothills of the Andes of central southern Peru.

936 Note: Recognition of A. a. dimidiatus follows O'Neill and Gardner (1974). A. a. cyanolaemus is 937 blue-throated (Fig. 1). 


\section{Table $\mathbf{1}$ (on next page)}

Treatments of species-level diversity in the genus Aulacorhynchus.

Table 1. Treatments of species-level diversity in the genus Aulacorhynchus. Taxa historically recognized only as subspecies are not included (see text for these taxa in "prasinus"). An X means the taxon was treated as a species, a dash indicates not available to be treated yet, and a blank indicates that the taxon was not considered. 
Table 1. Treatments of species-level diversity in the genus Aulacorhynchus. Taxa historically recognized only as subspecies are not included (see text for these taxa in "prasinus"). An X means the taxon was treated as a species, a dash indicates not available to be

3 treated yet, and a blank indicates that the taxon was not considered.

\begin{tabular}{|c|c|c|c|c|c|c|c|c|c|c|}
\hline & $\begin{array}{l}\text { Sclater } \\
(1891)\end{array}$ & $\begin{array}{c}\text { S \& G } \\
(1896) a \\
\text { B \& C } \\
(1912) b\end{array}$ & Cory (1919) & Peters (1948) & $\begin{array}{c}\text { Sibley \& } \\
\text { Monroe } \\
(1990)\end{array}$ & $\begin{array}{c}\text { Short \& } \\
\text { Horne (2001) }\end{array}$ & $\begin{array}{c}\text { Nav. et al. } \\
\text { (2001)g } \\
\text { P-O et al. } \\
(2008) g \\
\text { B. et al. }(2011) g\end{array}$ & $\begin{array}{c}\text { Dickinson \& } \\
\text { Remsen } \\
(2013) i\end{array}$ & $\begin{array}{l}\text { del Hoyo \& } \\
\text { Collar (2014) }\end{array}$ & this arti \\
\hline A. sulcatus & $x$ & $\times$ & $\times$ & $\times$ & $\times$ & $\times$ & $\times$ & $x$ & $\times$ & \\
\hline A. erythrognathus & $x$ & $x$ & ssp. of sulcatus & ssp. of sulcatus & & ssp. of sulcatus & ssp. of sulcatus & $\begin{array}{l}\text { ssp. of } \\
\text { sulcatus }\end{array}$ & ssp. of sulcatus & \\
\hline A. calorhynchus & $x$ & $x$ & $x$ & $x$ & $\begin{array}{l}\text { ssp. of } \\
\text { sulcatus }\end{array}$ & ssp. of sulcatus & ssp. of sulcatus & $\begin{array}{l}\text { ssp. of } \\
\text { sulcatus }\end{array}$ & $\times$ & \\
\hline A. derbianus & $x$ & $x$ & $x$ & $\times$ & $x$ & $\times$ & $\times$ & $x$ & $x$ & \\
\hline A. whitelianus & $x$ & $x$ & $x$ & $\begin{array}{c}\text { ssp. of } \\
\text { derbianus }\end{array}$ & & $\begin{array}{c}\text { ssp. of } \\
\text { derbianus }\end{array}$ & $x$ & $x$ & $x$ & \\
\hline A. haematopygus & $x$ & $x$ & $x$ & $\times$ & $x$ & $\times$ & $x$ & $x$ & $x$ & \\
\hline A. caeruleicinctis & $x$ & $x$ & $x$ & $x$ & $x$ & $x$ & $x$ & $x$ & $x$ & \\
\hline A. huallagae & $-c$ & $-c$ & $-c$ & $x$ & $x$ & $x$ & $x$ & $x$ & $x$ & \\
\hline A. prasinus & $x$ & $x$ & $x$ & $x$ & $x$ & $x$ & $x$ & $\times$ & $x$ & $x$ \\
\hline A. wagleri & $x$ & $x$ & $x$ & ssp. of prasinus & & ssp. of prasinus & $x$ & $\begin{array}{l}\text { ssp. of } \\
\text { prasinus }\end{array}$ & $x$ & $x$ \\
\hline A. caeruleogularis & $x$ & $x$ & $\times$ & ssp. of prasinus & $\begin{array}{l}\text { ssp. of } \\
\text { prasinus }\end{array}$ & ssp. of prasinus & $x$ & $\begin{array}{l}\text { ssp. of } \\
\text { prasinus }\end{array}$ & 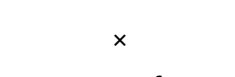 & $x$ \\
\hline A. cognatus & $-d$ & $-d$ & $\begin{array}{c}\text { ssp. of } \\
\text { caeruleogularis }\end{array}$ & ssp. of prasinus & & ssp. of prasinus & $x$ & $\begin{array}{l}\text { ssp. of } \\
\text { prasinus }\end{array}$ & $\begin{array}{c}\text { ssp. of } \\
\text { caeruleogularis }\end{array}$ & $\begin{array}{r}\text { ssp. c } \\
\text { caeruleog }\end{array}$ \\
\hline A. albivitta & $x$ & $x$ & 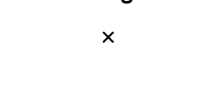 & ssp. of prasinus & & ssp. of prasinus & $x$ & $\begin{array}{l}\text { ssp. of } \\
\text { prasinus }\end{array}$ & 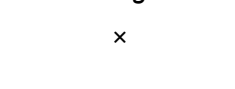 & $x$ \\
\hline A. griseigularis & $-e$ & $-e$ & $-e$ & ssp. of prasinus & & ssp. of prasinus & $x$ & prasinus & ssp. of albivitta & ssp. of alk \\
\hline A. lautus & $-f$ & $x$ & $x$ & ssp. of prasinus & & ssp. of prasinus & $\times h$ & $\begin{array}{l}\text { ssp. of } \\
\text { prasinus }\end{array}$ & ssp. of albivitta & ssp. of alk \\
\hline A. cyanolaemus & $x$ & $x$ & $x$ & ssp. of prasinus & & ssp. of prasinus & $\begin{array}{l}\text { ssp. of } \\
\text { atrogularis }\end{array}$ & $\begin{array}{l}\text { ssp. of } \\
\text { prasinus }\end{array}$ & $x$ & ssp. of atro \\
\hline A. dimidiatus & $x$ & $x$ & $x$ & ssp. of prasinus & & ssp. of prasinus & $\begin{array}{c}\text { ssp. of } \\
\text { atrogularis }\end{array}$ & $\begin{array}{c}\text { ssp. of } \\
\text { prasinus }\end{array}$ & ssp. of atrogularis & ssp. of atro \\
\hline A. atrogularis & $x$ & $x$ & $x$ & ssp. of prasinus & & ssp. of prasinus & $x$ & $\begin{array}{l}\text { ssp. of } \\
\text { prasinus }\end{array}$ & $\times$ & $x$ \\
\hline
\end{tabular}

5 a-Salvin \& Godman (1896) treated only Middle American Aulacorhynchus, which at the time were considered Aulacorhamphus. 
$6 \quad \mathrm{~b}$ - Brabourne and Chubb (1912) treated South American members of the genus (then considered Aulacorhamphus).

7 c-huallagae was described by Carriker (1933).

8 d-cognatus was described as a subspecies by Nelson (1912).

9 e-griseigularis was described as a subspecies by Chapman (1915).

$10 \mathrm{f}$-lautus was described by Bangs (1898).

$11 \mathrm{~h}$ - though not included in either study.

$12 \mathrm{i}$ - Treatment matches the South American Classification Committee (Remsen et al. 2016). 


\section{Table 2 (on next page)}

Color and pattern-based diagnostic characteristics

Table 2. Color and pattern-based diagnostic characteristics of the six major subspecific groups of Aulacorhynchus "prasinus" (based on specimens and del Hoyo and Collar 2014). Middle American forms are at left; South American forms are at right. 
1 Table 2. Color and pattern-based diagnostic characteristics of the six major subspecific groups of

2 Aulacorhynchus "prasinus" (based on specimens and del Hoyo and Collar 2014). Middle

3 American forms are at left; South American forms are at right.

4

5

\begin{tabular}{|l|l|}
\hline $\begin{array}{l}\text { A. “p." wagleri (monotypic): greatly enhanced } \\
\text { orange, paedomorphic bill encrustations at the very } \\
\text { base of upper mandible; orange band at base of } \\
\text { lower mandible; broad black base of upper } \\
\text { mandible; yellowish-white forehead grading to } \\
\text { olive crown; pale bluish-green underparts. }\end{array}$ & $\begin{array}{l}\text { A. "p." albivitta (incl. subspp. A. "p." lautus, } \\
\text { griseigularis, phaeolaemus, and albivitta): } \\
\text { yellowish skin surrounds more than half the eye; } \\
\text { variable chin and throat (white, grayish, pale gray- } \\
\text { blue); chestnut at base of lower mandible in most. }\end{array}$ \\
\hline $\begin{array}{l}\text { A.p. prasinus (incl. subspp. } \text { A. p. prasinus, } \\
\text { warneri, virescens, and volcanius): upper mandible } \\
\text { broadly yellow to base; black patches at nares; } \\
\text { bright yellow stripe at base of mandible; white } \\
\text { cheeks below eye. }\end{array}$ & $\begin{array}{l}\text { A. "p." cyanolaemus (monotypic): upper mandible } \\
\text { mostly black; pinkish skin around part of eye; deep } \\
\text { blue-gray chin and upper throat with little to none } \\
\text { on cheek. }\end{array}$ \\
\hline $\begin{array}{l}\text { A. "p." caeruleogularis (incl. subspp. A. "p." } \\
\text { caeruleogularis and cognatus): deep rich blue chin, } \\
\text { throat, and cheek; rich olive crown and nape in } \\
\text { absence of pale throat. }\end{array}$ & $\begin{array}{l}\text { A. "p." atrogularis (incl. subspp. A. "p." } \\
\text { atrogularis and dimidiatus): strongly bi-colored, } \\
\text { orange-yellow vs. white basal bill stripe going from } \\
\text { upper to lower mandibles; black chin, throat, and } \\
\text { cheek; dark skin around eye (only one of group in } \\
\text { South America). }\end{array}$ \\
\hline
\end{tabular}

6 


\section{Table 3(on next page)}

Mensural characteristics of both sexes among six major groups of the Aulacorhynchus "prasinus" complex

Table 3. Mensural characteristics of both sexes among six major groups of the

Aulacorhynchus "prasinus" complex. Units are mm except for mass $(\mathrm{g})$ and sample size $(N)$. 
1 Table 3. Mensural characteristics of both sexes among six major groups of the Aulacorhynchus "prasinus" complex. Units are mm except for 2 mass (g) and sample size $(N)$.

\begin{tabular}{|c|c|c|c|c|c|c|c|c|c|c|c|c|c|}
\hline & & \multicolumn{2}{|c|}{ prasinus } & \multicolumn{2}{|c|}{ wagleri } & \multicolumn{2}{|c|}{ caeruleogularis } & \multicolumn{2}{|c|}{ albivitta } & \multicolumn{2}{|c|}{ cyanolaemus } & \multicolumn{2}{|c|}{ atrogularis } \\
\hline & & M & $\mathrm{F}$ & M & $\mathrm{F}$ & M & $\mathrm{F}$ & M & $\mathrm{F}$ & M & $\mathrm{F}$ & M & $\mathrm{F}$ \\
\hline \multirow[t]{5}{*}{ Mass (g) } & mean & 186.6 & 171.2 & 169.7 & 172.0 & 152.8 & 158.5 & - & - & 176.7 & 158.8 & 158.1 & 112.5 \\
\hline & s.d. & 20.98 & 24.78 & 14.10 & 15.94 & 24.67 & 5.72 & - & - & 23.57 & 28.53 & 25.23 & 2.50 \\
\hline & $\min$ & 153.6 & 135 & 145 & 127 & 118 & 154 & - & - & 160 & 130 & 124 & 110 \\
\hline & $\max$ & 239.2 & 229.6 & 200 & 189.3 & 184 & 166.6 & - & - & 210 & 210 & 188 & 115 \\
\hline & $N$ & 13 & 11 & 13 & 14 & 8 & 3 & - & - & 3 & 5 & 8 & 2 \\
\hline & & & & & & & & & & & & & \\
\hline \multirow{5}{*}{$\begin{array}{l}\text { Wing chord } \\
\text { (WCH) }\end{array}$} & mean & 124.1 & 119.6 & 125.9 & 123.3 & 120.0 & 116.5 & 128.1 & 125.5 & 127.1 & 125.0 & 122.4 & 118.0 \\
\hline & s.d. & 4.58 & 4.95 & 3.80 & 3.64 & 4.90 & 4.38 & 4.26 & 3.24 & 5.78 & 3.62 & 6.07 & 7.00 \\
\hline & $\min$ & 113.1 & 106.4 & 117.4 & 117.4 & 103.5 & 104.0 & 118.6 & 117.7 & 114.0 & 119.9 & 108.1 & 105.5 \\
\hline & $\max$ & 135.0 & 130.7 & 136.7 & 132.3 & 133.1 & 125.6 & 139.5 & 132.4 & 137.8 & 131.2 & 133.6 & 129.6 \\
\hline & $N$ & 98 & 74 & 28 & 26 & 105 & 50 & 86 & 57 & 9 & 10 & 17 & 11 \\
\hline & & & & & & & & & & & & & \\
\hline Tail & mean & 109.7 & 105.0 & 113.1 & 111.8 & 98.4 & 94.6 & 109.8 & 106.4 & 106.8 & 109.1 & 112.2 & 106.3 \\
\hline (TL) & s.d. & 6.01 & 6.48 & 5.15 & 4.42 & 5.04 & 4.60 & 6.90 & 5.90 & 2.14 & 6.92 & 4.89 & 7.62 \\
\hline & $\min$ & 95.9 & 90.8 & 101.8 & 103.8 & 84.3 & 85.1 & 92.1 & 91.5 & 102.1 & 96.4 & 102.9 & 94.1 \\
\hline
\end{tabular}




\begin{tabular}{|c|c|c|c|c|c|c|c|c|c|c|c|c|c|}
\hline 22 & $\max$ & 124.4 & 119.0 & 122.7 & 121.9 & 116.1 & 106.9 & 127.0 & 120.5 & 109.2 & 118.6 & 119.8 & 118.0 \\
\hline 23 & $N$ & 94 & 71 & 28 & 25 & 99 & 48 & 84 & 57 & 8 & 10 & 16 & 11 \\
\hline \\
\hline Tarso- & & & & & & & & & & & & & \\
\hline metatarsus & mean & 32.4 & 31.5 & 32.5 & 31.7 & 32.3 & 31.3 & 32.9 & 32.0 & 32.8 & 31.5 & 31.4 & 29.8 \\
\hline (TS) & s.d. & 1.45 & 1.44 & 0.99 & 0.99 & 1.33 & 1.24 & 1.29 & 1.18 & 1.26 & 1.46 & 2.19 & 1.95 \\
\hline 28 & $\min$ & 28.1 & 27.9 & 29.0 & 29.7 & 29.2 & 29.0 & 29.4 & 28.7 & 31.1 & 28.8 & 26.8 & 26.7 \\
\hline 29 & $\max$ & 35.8 & 35.1 & 34.6 & 33.4 & 35.7 & 34.8 & 35.5 & 35.2 & 35.0 & 34.2 & 35.6 & 33.6 \\
\hline 30 & $N$ & 98 & 75 & 28 & 26 & 105 & 50 & 86 & 57 & 9 & 10 & 17 & 11 \\
\hline \\
\hline Bill & mean & 71.2 & 57.9 & 71.4 & 61.2 & 58.8 & 48.6 & 64.5 & 52.9 & 65.4 & 54.8 & 68.0 & 54.9 \\
\hline (BL) & s.d. & 5.75 & 4.62 & 4.70 & 3.77 & 3.82 & 3.97 & 4.96 & 4.29 & 5.18 & 2.15 & 5.57 & 6.45 \\
\hline 34 & $\min$ & 58.4 & 49.1 & 64.0 & 55.2 & 45.2 & 42.1 & 54.3 & 43.8 & 55.1 & 50.8 & 59.9 & 46.7 \\
\hline 35 & $\max$ & 84.7 & 71.9 & 84.6 & 69.7 & 69.2 & 68.1 & 73.3 & 68.0 & 75.1 & 59.4 & 79.8 & 69.2 \\
\hline 36 & $N$ & 98 & 75 & 28 & 26 & 105 & 50 & 86 & 57 & 9 & 10 & 17 & 11 \\
\hline \multicolumn{14}{|l|}{37} \\
\hline Bill height & mean & 24.2 & 22.7 & 23.3 & 22.6 & 22.3 & 20.9 & 23.3 & 21.7 & 23.1 & 22.4 & 24.7 & 22.5 \\
\hline$(\mathrm{BLH})$ & s.d. & 1.13 & 1.18 & 0.99 & 0.89 & 1.00 & 0.99 & 1.05 & 1.04 & 1.95 & 0.65 & 2.28 & 1.78 \\
\hline 40 & $\min$ & 20.8 & 20.7 & 20.9 & 21.3 & 19.6 & 19.1 & 20.2 & 19.3 & 18.9 & 21.2 & 22.9 & 20.0 \\
\hline 41 & $\max$ & 26.7 & 25.1 & 25.7 & 25.0 & 25.2 & 23.6 & 25.7 & 24.2 & 25.0 & 23.5 & 33.1 & 26.2 \\
\hline 42 & $N$ & 97 & 75 & 28 & 26 & 104 & 50 & 86 & 57 & 9 & 10 & 17 & 11 \\
\hline
\end{tabular}

43 


\begin{tabular}{|c|c|c|c|c|c|c|c|c|c|c|c|c|c|c|}
\hline 44 & Bill width & mean & 21.1 & 20.1 & 21.3 & 21.1 & 21.0 & 20.2 & 21.5 & 20.4 & 20.4 & 19.5 & 21.3 & 19.7 \\
\hline 45 & (BLW) & s.d. & 1.01 & 0.99 & 0.72 & 0.94 & 1.06 & 1.07 & 1.06 & 1.03 & 1.13 & 0.77 & 1.06 & 1.50 \\
\hline 46 & & $\min$ & 18.7 & 17.7 & 20.0 & 19.0 & 17.8 & 18.2 & 19.0 & 17.7 & 18.3 & 18.5 & 19.2 & 17.4 \\
\hline 47 & & $\max$ & 23.4 & 23.5 & 22.7 & 23.4 & 23.5 & 24.0 & 24.4 & 22.9 & 22.4 & 21.1 & 22.8 & 22.8 \\
\hline 48 & & $N$ & 98 & 75 & 28 & 26 & 105 & 50 & 86 & 57 & 9 & 10 & 17 & 11 \\
\hline 49 & & & & & & & & & & & & & & \\
\hline 50 & Wing tip & mean & 16.9 & 16.7 & 18.2 & 17.9 & 16.8 & 16.4 & 16.6 & 15.9 & 16.7 & 16.6 & 17.0 & 16.5 \\
\hline 51 & (WGTP) & s.d. & 2.56 & 2.78 & 2.15 & 1.94 & 2.06 & 2.37 & 2.24 & 1.87 & 1.32 & 1.77 & 3.02 & 2.13 \\
\hline 52 & & $\min$ & 11.4 & 9.9 & 13.2 & 13.3 & 10.8 & 9.7 & 11.5 & 12.1 & 14.3 & 14.3 & 11.2 & 11.4 \\
\hline 53 & & $\max$ & 24.0 & 23.0 & 22.8 & 21.3 & 22.8 & 21.9 & 22.5 & 20.0 & 18.1 & 19.4 & 22.6 & 19.2 \\
\hline 54 & & $N$ & 95 & 69 & 28 & 26 & 104 & 49 & 86 & 57 & 9 & 10 & 17 & 11 \\
\hline
\end{tabular}




\section{Table 4 (on next page)}

Patterns of significance from results of $t$-tests of mensural characters between geographic pairs of major subspecific group

Table 4. Patterns of significance from results of $t$-tests of mensural characters between geographic pairs of major subspecific groups of Aulacorhynchus "prasinus." Positive (+) values indicate that the first named group averages larger, while negatives (-) indicate that the second is the larger. Character abbreviations follow Table 3. 
1 Table 4. Patterns of significance from results of $t$-tests of mensural characters between

2 geographic pairs of major subspecific groups of Aulacorhynchus "prasinus." Positive (+) values

3 indicate that the first named group averages larger, while negatives (-) indicate that the second is

4 the larger. Character abbreviations follow Table 3.

7

8

9

10

11

13

14

15

16

17

18

19

20

21

22

23

24

25

26

27

28

29

30

31

32

33

34

\begin{tabular}{|c|c|c|c|c|c|c|c|c|c|}
\hline Pairs compared & Sex & $\mathrm{WCH}$ & TL & $\mathrm{TS}$ & $\mathrm{BL}$ & $\mathrm{BLH}$ & BLW & WGTP & $\mathrm{N}$ \\
\hline \multirow[t]{2}{*}{ prasinus-wagleri } & M & & $* *(-)$ & & & $* * *(+)$ & & $*(-)$ & 98,28 \\
\hline & $\mathrm{F}$ & $* *(-)$ & $* * *(-)$ & & $* * *(-)$ & & $* *(-)$ & & 75,26 \\
\hline \multirow[t]{2}{*}{ prasinus-caeruleogularis } & M & $* * *(+)$ & $* * *(+)$ & & $* * *(+)$ & $* * *(+)$ & & & 98,105 \\
\hline & $\mathrm{F}$ & $* * *(+)$ & $* * *(+)$ & & $* * *(+)$ & $* * *(+)$ & & & 75,50 \\
\hline \multirow{2}{*}{ caeruleogularis-albivitta } & M & $* * *(-)$ & $* * *(-)$ & $* *(-)$ & $* * *(-)$ & $* * *(-)$ & $* *(-)$ & & 105,86 \\
\hline & $\mathrm{F}$ & $* * *(-)$ & $* * *(-)$ & $* *(-)$ & $* * *(-)$ & $* * *(-)$ & & & 50,57 \\
\hline \multirow[t]{2}{*}{ albivitta-cyanolaemus } & M & & $*(+)$ & & & & $*(+)$ & & 86,9 \\
\hline & $\mathrm{F}$ & & & & & $*(-)^{\mathrm{a}}$ & $*(+)$ & & 57,10 \\
\hline \multirow[t]{2}{*}{ cyanolaemus-atrogularis } & M & & $* *(-)$ & & & & & & 9,17 \\
\hline & $\mathrm{F}$ & $*(+)$ & & $*(+)^{\mathrm{a}}$ & & & & & 10,11 \\
\hline \multirow[t]{2}{*}{ albivitta-atrogularis } & & M & $* *(+)$ & & $*(+)$ & $*(-)$ & $*(-)$ & & 86,17 \\
\hline & $\mathrm{F}$ & $* *(+)$ & & $* *(+)$ & & & & & 57,11 \\
\hline
\end{tabular}




\section{Table 5 (on next page)}

Patterns of significance from results of $t$-tests comparing individual principal component (PC) scores

Table 5. Patterns of significance from results of $t$-tests comparing individual principal component (PC) scores between geographic pairs of major subspecific groups of Aulacorhynchus "prasinus." PC scores are from the first two principal components. Individuals with missing values were excluded. Underlined asterisks indicate significance after false discovery rate correction for multiple tests. 
1 Table 5. Patterns of significance from results of $t$-tests comparing individual principal

2 component (PC) scores between geographic pairs of major subspecific groups of

3 Aulacorhynchus "prasinus." PC scores are from the first two principal components. Individuals

4 with missing values were excluded. Underlined asterisks indicate significance after false

5 discovery rate correction for multiple tests.

\begin{tabular}{|c|c|c|c|c|}
\hline Pairs compared & Sex & $\mathrm{PC} 1$ & $\mathrm{PC} 2$ & $\mathrm{~N}$ \\
\hline prasinus-wagleri & $\begin{array}{l}\mathrm{M} \\
\mathrm{F}\end{array}$ & $\begin{array}{c}* \\
* * * \\
\end{array}$ & $*$ & $\begin{array}{l}90,28 \\
65,25\end{array}$ \\
\hline prasinus-caeruleogularis & $\begin{array}{l}\mathrm{M} \\
\mathrm{F}\end{array}$ & $\frac{* *}{* * *}$ & $* * *$ & $\begin{array}{l}90,98 \\
65,48\end{array}$ \\
\hline caeruleogularis-albivitta & $\begin{array}{l}\mathrm{M} \\
\mathrm{F}\end{array}$ & $* * *$ & $\frac{* * *}{* * *}$ & $\begin{array}{l}98,84 \\
48,57\end{array}$ \\
\hline albivitta-cyanolaemus & $\begin{array}{l}\mathrm{M} \\
\mathrm{F}\end{array}$ & & & $\begin{array}{c}84,8 \\
57,10\end{array}$ \\
\hline cyanolaemus-atrogularis & $\begin{array}{l}\mathrm{M} \\
\mathrm{F}\end{array}$ & & $*$ & $\begin{array}{c}8,16 \\
10,11\end{array}$ \\
\hline albivitta-atrogularis & $\begin{array}{l}\mathrm{M} \\
\mathrm{F}\end{array}$ & & $*$ & $\begin{array}{l}84,16 \\
57,11\end{array}$ \\
\hline $\begin{array}{l}*-P<0.05 \\
* *-P<0.01 \\
* * *-P<0.001\end{array}$ & & & & \\
\hline
\end{tabular}




\section{Figure 1}

The six major, color-based taxonomic groups of the Aulacorhynchus "prasinus" species complex

Figure 1. The six major, color-based taxonomic groups of the Aulacorhynchus "prasinus" species complex, from top to bottom: A) wagleri; B) prasinus (nominate prasinus and warneri, the full-bodied bird, are portrayed): C) caeruleogularis; D) albivitta (griseigularis and nominate albivitta are portrayed); E) cyanolaemus (yellow-tipped bill); and F) atrogularis. 

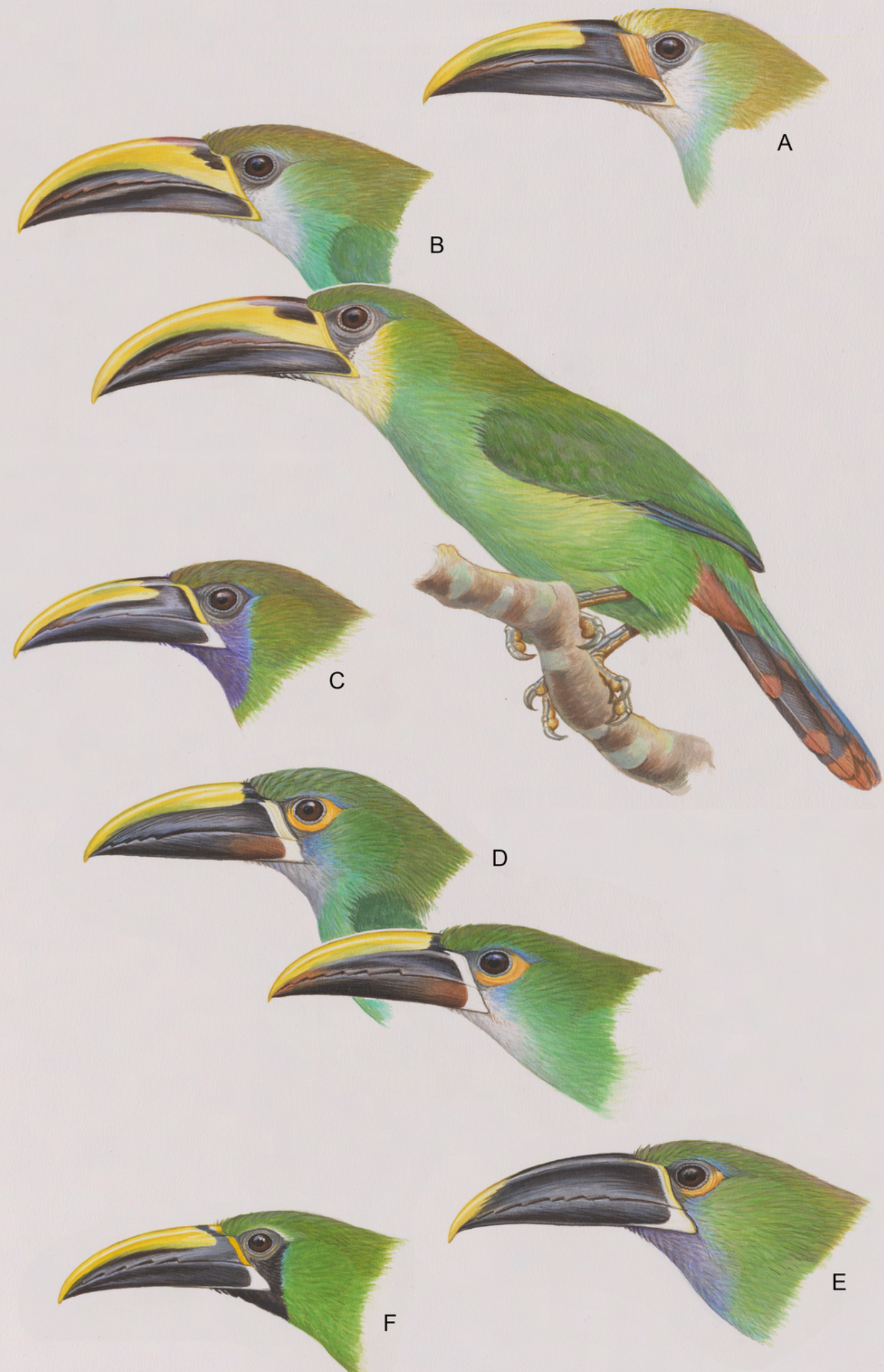
Figure 2 (on next page)

Distributions of the specimens of Aulacorhynchus "prasinus" examined in this study

Figure 2. Distributions of the specimens of Aulacorhynchus "prasinus" examined in this study with the focal six major subspecific groups labeled. Neither all specimens in existence nor observation records are included, so ranges are not complete. Red stars indicate evidence of hybridization; the top-most one, in Ecuador, is from the study of Puebla-Olivares et al. (2008). 


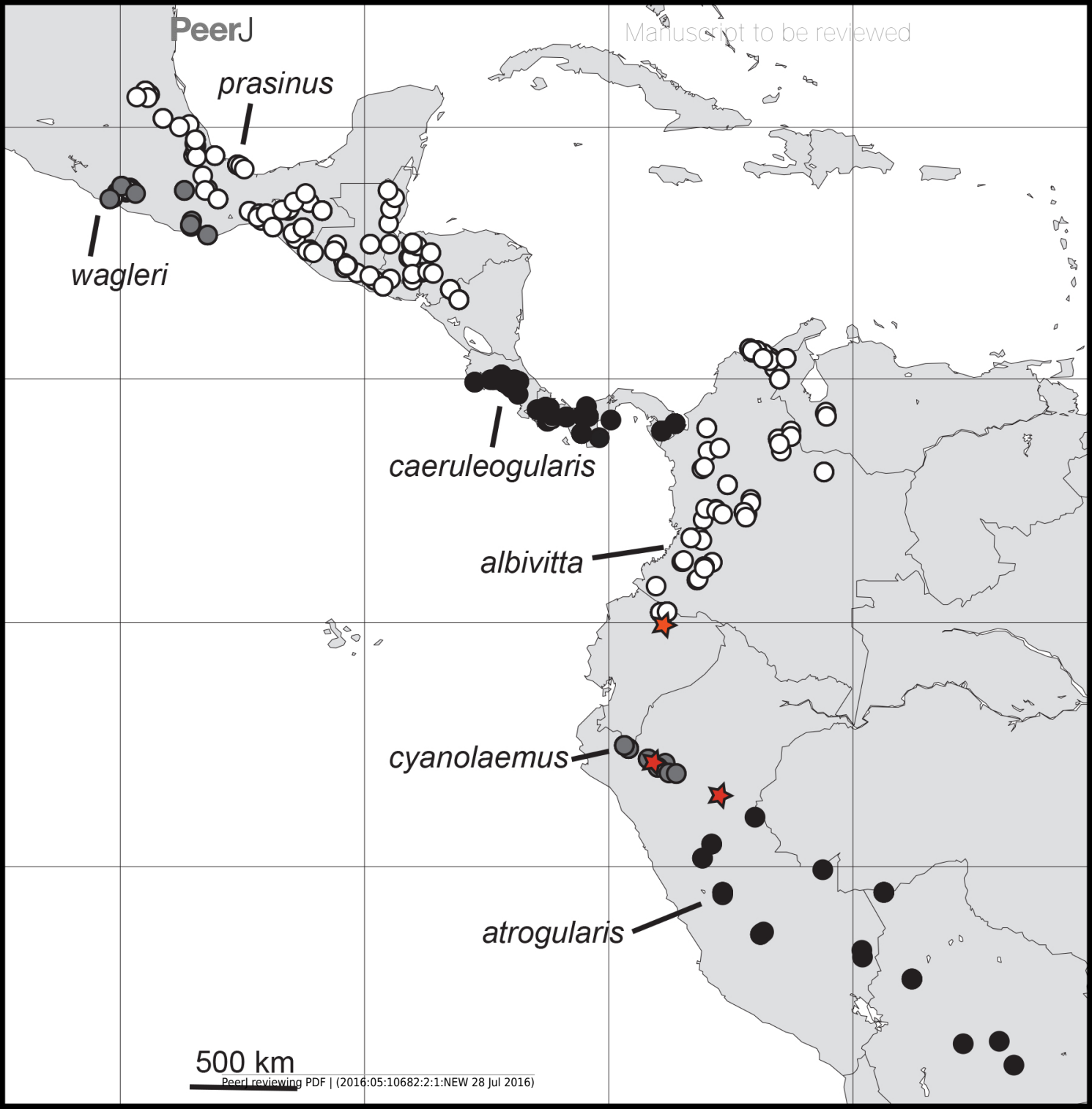


Figure 3

An example of a hybrid

Figure 3. An example of a hybrid A. "p." atrogularis $\times A$. "p." cyanolaemus. A) a pure A. "p." cyanolaemus (LSU 87627); B) a hybrid (LSU 92029); and C) a pure A. "p." atrogularis (LSU 73933). 


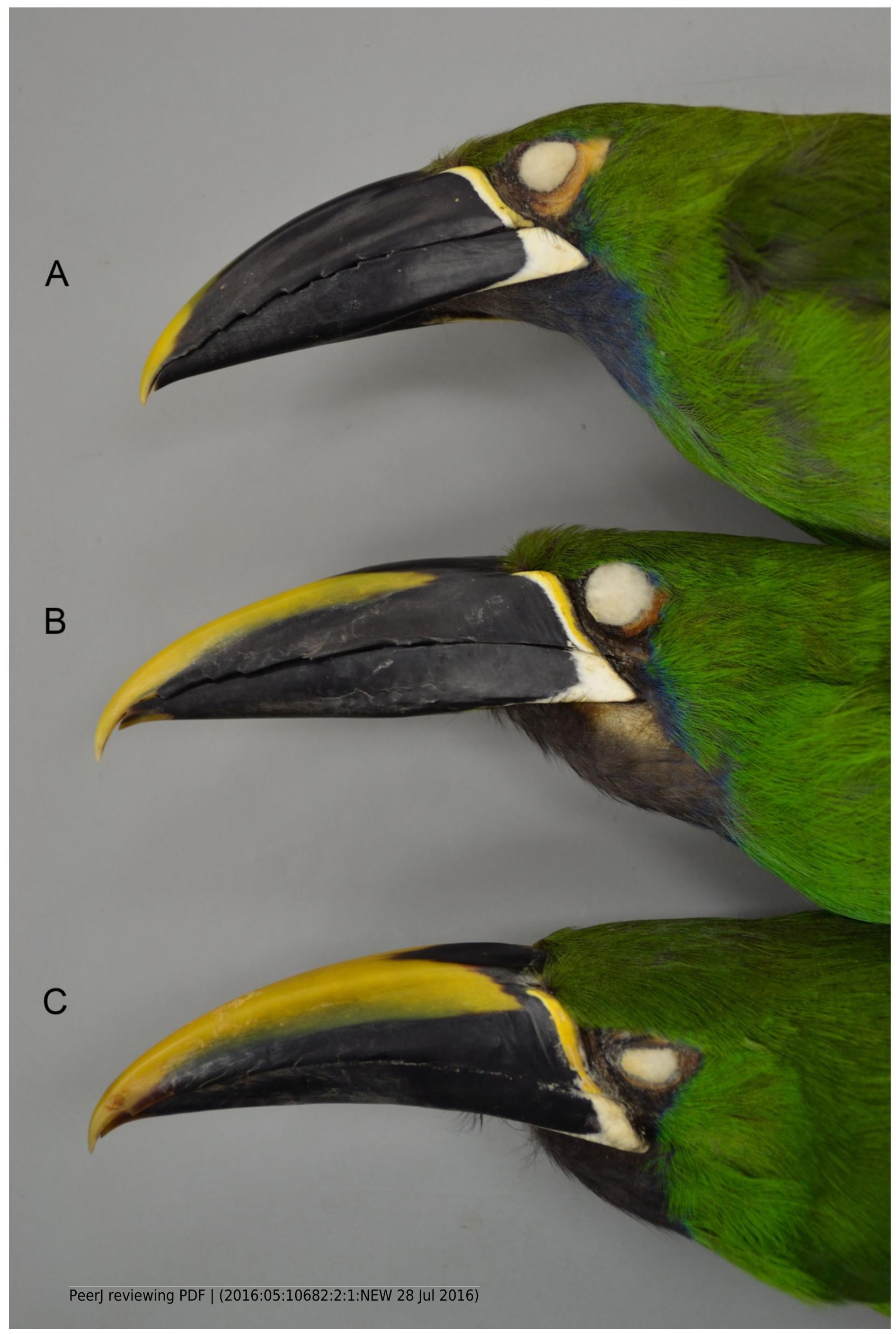




\section{Figure 4}

The mtDNA topology of the relationships among the six major subspecific groups, following Puebla-Olivares et al. (2008).

Figure 4. The mtDNA topology of the relationships among the six major subspecific groups, following Puebla-Olivares et al. (2008). Taxa labeled with a " $(+)$ " are non-monophyletic in mtDNA. Values between the major subspecific groups are the between-group mean genetic distances between them.

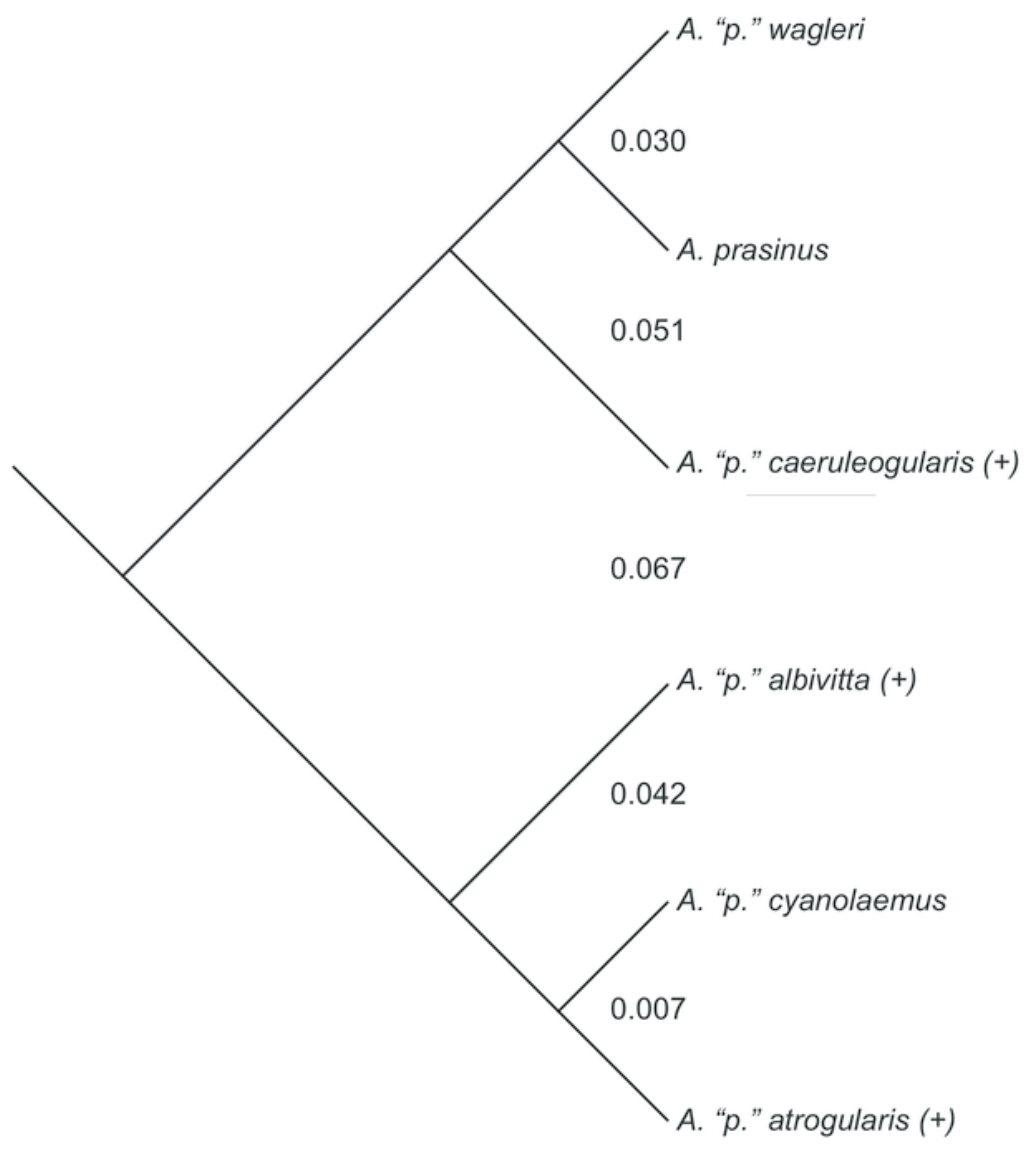


Figure $\mathbf{5}$ (on next page)

The relationship between genetic distance (Figure 3 ) and the accumulation of morphometric differences (Table 4)

Figure 5. The relationship between genetic distance (Figure 3) and the accumulation of morphometric differences (Table 4) between the major subspecific groups that might hybridize due to proximity. The positive correlation is that predicted by the processes of anagenesis and speciation. 


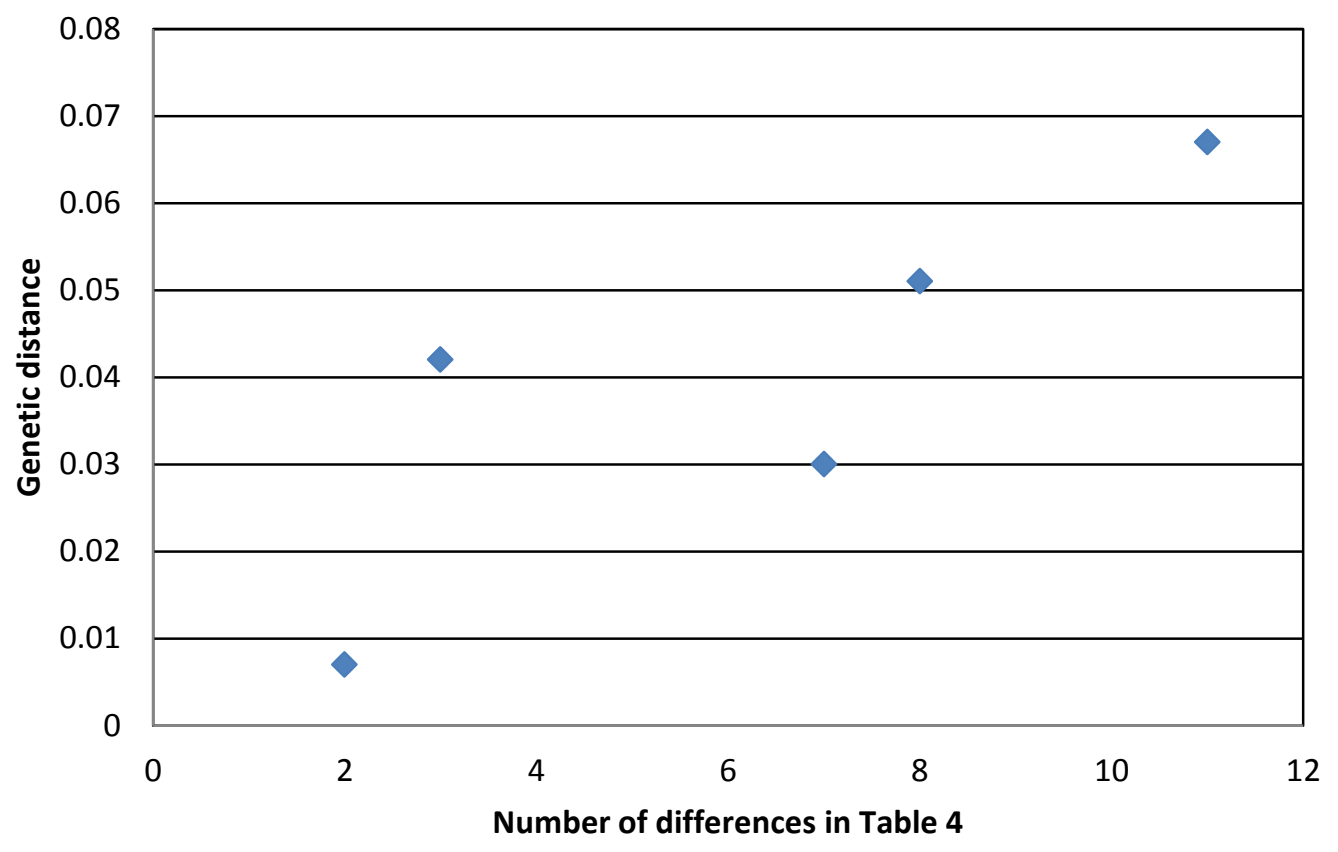

